\title{
Heavy Metal Uptake by Four Plant Species: Radish, Indian mustard, Corn, And Soybean.
}

\author{
Oluwasogo Bolaji Alonge
}

Follow this and additional works at: https://researchrepository.wvu.edu/etd

Part of the Environmental Health and Protection Commons, Natural Resources and Conservation Commons, Other Environmental Sciences Commons, and the Soil Science Commons

\section{Recommended Citation}

Alonge, Oluwasogo Bolaji, "Heavy Metal Uptake by Four Plant Species: Radish, Indian mustard, Corn, And Soybean." (2015). Graduate Theses, Dissertations, and Problem Reports. 8168.

https://researchrepository.wvu.edu/etd/8168

This Thesis is protected by copyright and/or related rights. It has been brought to you by the The Research Repository @ WVU with permission from the rights-holder(s). You are free to use this Thesis in any way that is permitted by the copyright and related rights legislation that applies to your use. For other uses you must obtain permission from the rights-holder(s) directly, unless additional rights are indicated by a Creative Commons license in the record and/ or on the work itself. This Thesis has been accepted for inclusion in WVU Graduate Theses, Dissertations, and Problem Reports collection by an authorized administrator of The Research Repository @ WVU. For more information, please contact researchrepository@mail.wvu.edu. 
Heavy Metal Uptake by Four Plant Species: Radish, Indian mustard, Corn, And Soybean

\author{
Oluwasogo Bolaji Alonge
}

Thesis Submitted to the Davis College of Agriculture, Natural Resources and Design at West Virginia University in partial fulfillment of the requirements for the degree of

\author{
Master of Sciences \\ in \\ Plant and Soil Sciences \\ Committee \\ Louis M. McDonald, Ph.D., Chair \\ Jeffrey Skousen Ph.D. \\ Nicole Waterland, Ph.D. \\ Division of Plant and Soil Sciences \\ West Virginia University, \\ Morgantown, West Virginia
}

Fall 2015 


\begin{abstract}
Metal contaminated soils are a problem throughout the world. Because metals accumulate in the food chain they have been linked to adverse human and ecosystem health. One promising approach to remediating metal contaminated soils is phytoremediation but success has been limited by an incomplete understanding of the factors that control metal uptake by plants, including the effects when more than one contaminant metal is present in the system. Metal contaminated soil for this study was collected from near Spelter in Harrison County WV, the site of a former zinc smelting site that has contaminated residential soils and stream sediments with zinc, lead, cadmium, copper and other elements of concern. The ability of four important agricultural crops- radish (Raphinus sativus var. Cheriette); Indian mustard (Brassica juncea var. Mighty Mustard); corn (Zea mays var. Luscious, Hybrid Bicolor); and soybean (Glycine max var. Butterbean) to accumulate heavy metals and associated possible soil-plant interactions were investigated in a pot study. The first experiment quantified the uptake of zinc, lead, cadmium, copper and manganese as growth progressed from dry seeds to hydrated seeds to cotyledons and then to the roots, stems and leaves of the four species listed above. A second, smaller experiment incubated the Spelter soil with increasing concentrations of lead nitrate to determine if there were interactions in metal uptake by radish.

The result shows that the potential for metal accumulation differs greatly among the four species. Radish, Indian mustard, and soybean showed a higher potential for metal uptake and accumulations compared to the monocot-corn. Metal accumulation from this study were in this order;

$\mathrm{Zn}>\mathrm{Mn}>\mathrm{Cu}>\mathrm{Pb}>\mathrm{Cd}$. Cadmium levels in this study were low but above guidance levels and thus, could contribute to the total body burden of $\mathrm{Cd}$ in humans. Among the four species, soybean roots had the highest $\mathrm{Pb}$ uptake but it was not translocated to the stems or leaves. In contrast, radish and Indian mustard had the highest translocation of $\mathrm{Pb}$ to stems and leaves, whereas corn did not accumulate or translocate appreciable $\mathrm{Pb}$. Incubating a multi-metal contaminated soil with lead nitrate resulted in synergistic and antagonistic $\mathrm{Zn}$ uptake in radish and weaker synergistic effects for $\mathrm{Cd}, \mathrm{Cu}$ and $\mathrm{Mn}$.

Overall, this work demonstrated that there was an observable trend for tissue $\mathrm{Zn}, \mathrm{Pb}, \mathrm{Cu}$, and $\mathrm{Cd}$ concentrations to increase starting from seed imbibition, to cotyledon, to whole plants; except for $\mathrm{Mn}$, where that there was no clear trend. Also this study established that heavy metal uptake was not only metal specific but also species specific. For example when we compared results for soybean with corn, we determined that soybean removed more metal and thus a better accumulator of metals. Interestingly, the two members of the family Brassicaceae-radish and Indian mustard had similar efficiency to accumulate metals in multi-contaminated soils. The results also suggested that current approaches to characterize the potential for metal uptake from multi-metal contaminated soils are inadequate. Specifically, that it is not possible to predict metal uptake without properly accounting for other metals in the system.
\end{abstract}




\section{ACKNOWLEDGEMENT}

I would like to use this opportunity to express a profound gratitude to everyone who made this project a success. I would also like to thank all who gave me moral support and encouragement in the course of this project. I am more than happy to see this project completion.

First, my heartwarming appreciation goes to my amiable advisor Dr. Louis McDonald. I definitely would not have followed this path without his initial approval and the great confidence he so much had in me. His enthusiasm, patience, expertise and undiluted assistance throughout the course of my master program is particularly sublime and I am greatly indebted to him for his kindness towards me.

I would also like to thank other members of my committee; Dr. Jeffrey Skousen and Dr. Nicole Waterland for their brilliant contributions and immeasurable effort in reading through the entire thesis. Special thanks also go to Dr. Domingo Mata Padrino and my one-time Brazilian office colleagues, Daniel Collucci. I would like to express my sincere appreciation to Joan Wright for helping me with ICP analysis throughout my lab work. Special thanks to Taiwo Ajayi and Tosin Oginni for their painstaking effort.

This dissertation is dedicated to the glory of the Almighty God who endowed me with profound capacity and unquantifiable strength towards this program. I thank God for He always been my help from the time immemorial. I would also like to thank my wonderful parents who have shown me this path earlier in life and my sister, Lola Alonge who has been a tremendous help to me. 


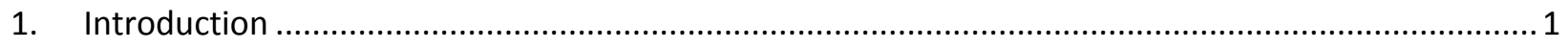

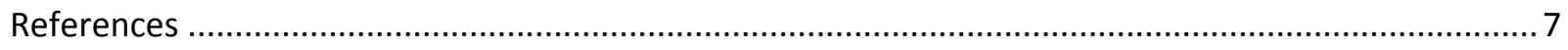

2. Metal Uptake by Radish, Indian mustard, Corn and Soybean from a

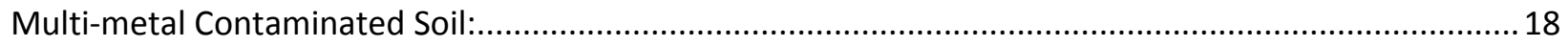

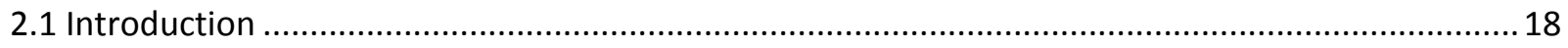

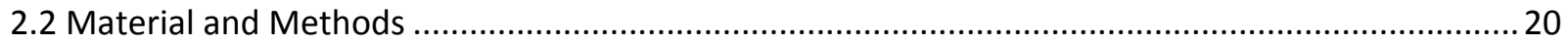

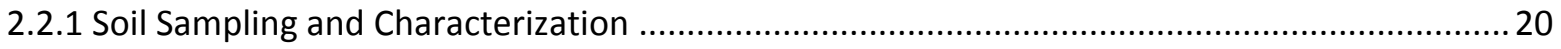

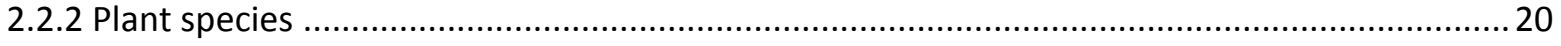

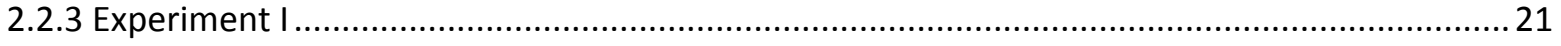

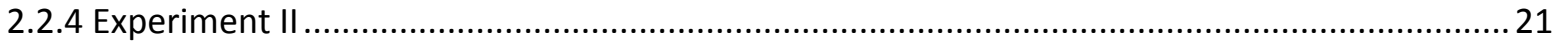

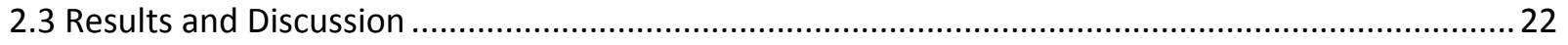

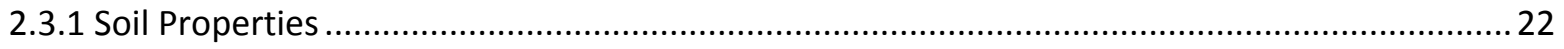

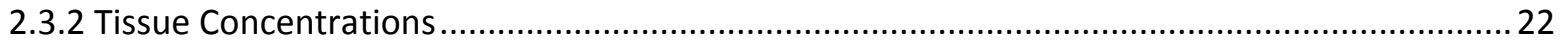

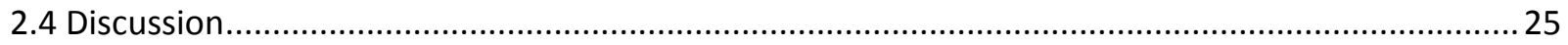

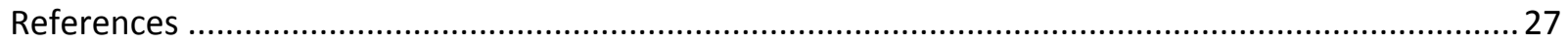

3. Effect of Lead Treatments on Radish Plant Uptake and Potential Interaction with Manganese, Zinc, Lead, Cadmium, and Copper ......................................................... 45

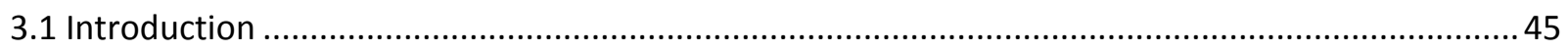

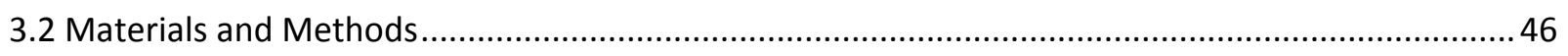

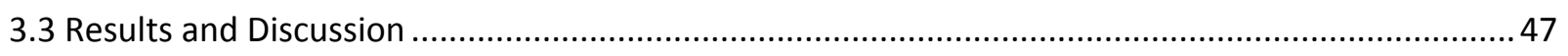

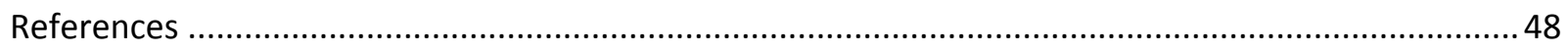

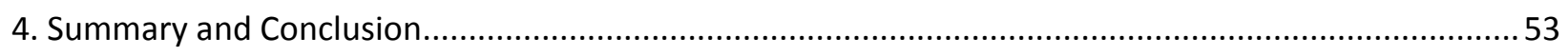

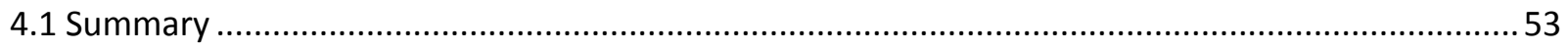




\section{List of Tables}

Table 1-1 Average concentrations and ranges for selected metals in uncontaminated soils and contaminated soil from Spelter, WV.

Table 2-1 Mean soil pH at the end of the experiment for Radish, Indian mustard, corn and soybean.

Initial soil pH was 5.2

Table 2-2 Mean and standard deviation (St. Dev.) for Mehlich 3 exchangeable fractions for $\mathrm{Cd}, \mathrm{Cu}, \mathrm{Zn}$, $\mathrm{Pb}, \mathrm{Mn}$, and $\mathrm{P}$ for the Spelter soil.

Table 2-3 Total Nitrogen (N), Total Carbon (C), Cd, Cu, Pb, Zn and concentrations in Spelter contaminated soil.

Table 2-4 Mean Cd concentration in radish, Indian mustard, corn, and soybean. .54

Table 2-5 Mean Cu concentration in radish, Indian mustard, corn, and soybean 55Error! Bookmark not defined.

Table 2-6 Mean Zn concentration in radish, Indian mustard, corn, and soybean. .56

Table 2-7 Mean Pb concentration in radish, Indian mustard, corn, and soybean. .57

Table 2-8 Mean Mn concentration in radish, Indian mustard, corn, and soybean... .58

Table 2-9 Interaction of $\mathrm{Pb}$ treatments on mean uptake $\mathrm{Cd}, \mathrm{Cu}, \mathrm{Zn}, \mathrm{Pb}$, and $\mathrm{Mn}$ in Radish leaf...... .59 


\section{List of Figures}

Figure 1-1 Aerial view of Spelter, WV, and the Spelter waste pile..................................................... 13

Figure 1-2 View of the waste pile in Spelter, WV ca 1989 from the banks of the West Fork River. ..........14

Figure 1-3 Factors that affect the uptake of heavy metals................................................................. 15

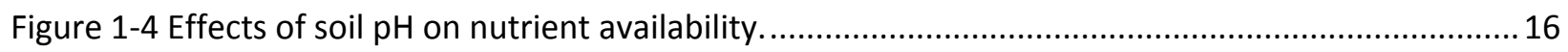

Figure 1-6 The mechanisms of heavy metals uptake by plant through phytoremediation technology......17

Figure 2-1. Mean Cd concentration in dry seeds, hydrated seeds, cotyledons (A) from the petri dish

experiment and roots, stems, and leaves (B) in the whole plant experiment..

Figure 2-2. Mean Cu concentration in dry seeds, hydrated seeds, cotyledons (A) from the petri dish experiment and roots, stems, and leaves (B) in the whole plant experiment.

Figure 2-3. Mean Zn concentration in dry seeds, hydrated seeds, cotyledons (A) from the petri dish experiment and roots, stems, and leaves (B) in the whole plant experiment...

Figure 2-5. Mean Pb concentration in dry seeds, hydrated seeds, cotyledons $(A)$ from the petri dish experiment and roots, stems, and leaves (B) in the whole plant experiment.

Figure 2-6. Mean Cu concentration in dry seeds, hydrated seeds, cotyledons (A) from the petri dish experiment and roots, stems, and leaves (B) in the whole plant experiment . .39

Figure 2-7 Marginal leaf chlorosis in soybean grown on Spelter soil attributed to Mn toxicity........

Figure 2-8 Hydrated Soybean cotyledon (after separation drom seed coats), and corn endosperm.

Figure 2-9 Emerged cotyledons of radish seeds after 24 hours.

Figure 2-10 Emerged cotyledon of Indian mustard seeds after 24 hours.

Figure 2-11 Separation of seed coat from the cotyledon, corn endosperm (10 day old), and soybean cotyledon (10 day old). .44

Figure 3-1 Effect of added lead nitrate on radish leaf zinc concentrations..............................................50

Figure 3-2 Effect of added lead nitrate on radish leaf $\mathrm{Pb}$ and $\mathrm{Mn}$ concentrations....................................51

Figure 3-3 Effect of added lead nitrate on radish leaf $\mathrm{Cd}$ and $\mathrm{Cu}$ concentrations. .53

Figure 2-12 Mean Cd concentration in roots, stems and leaves at eight weeks when grown in the greenhouse mix control and the Spelter soil. 
Figure 2-13 Mean Cu concentration in contaminated soil compared with uncontaminated at 8 week....61

Figure 2-14 Mean Zn concentration in contaminated soil compared with uncontaminated at 8 week....62

Figure 2-15 Mean Pb concentration in contaminated soil compared with uncontaminated at 8 week....63

Figure2-16 Mean Mn concentration in contaminated soil compared with uncontaminated at 8 week. ..64

Figure 2-17 Control plants grown on greenhouse media.......................................................................65 


\section{Introduction}

Heavy metals have been defined as metals or metalloids with a specific gravity greater than 5 . Heavy metal pollution, mostly from chemical industries and other anthropogenic activities, can result in soil contamination. Sources of this pollution include residues from mining and the smelting industry (Boon and Soltanpour, 1992; Cobb et al., 2000), municipal waste incinerators, burning of fossil fuels (including car exhausts), lead-based paint and the use of sludge or urban composts, pesticides and fertilizers. Several studies have been done on heavy metal/metalloid accumulation in plants and the hazards these elements pose to humans, animals and environment (Cui et al., 2005; Khan et al., 2008; Roy et al., 2013; Thompson et al., 1997).

The problems with this metal contamination on biota have been well documented (Meagher, 2000; Raskin and Ensley, 2000). Heavy metal contamination is a significant problem because unlike organic pollutants metals tend to accumulate (bioaccumulation), or persist (food web) in the environment and do not biodegrade (Pierzynski et al., 2005). It has been reported, for example, that lead $(\mathrm{Pb})$ and cadmium $(\mathrm{Cd})$ are probably the most abundant heavy metal pollutants in the environment (Watanabe., 1997; Xiong, 1998; Patra et al., 2011) and that they can accumulate quickly in important body organs such as the kidney and liver, and are difficult to eliminate. Young children and pregnant women are the human population most affected by metal toxicities. Neurological disorders, cancer, low birth weight and mental retardation in newborns have been attributed to metal toxicities (Brevik, 2013). This may occur through direct ingestion of contaminated water and food (e.g. Hg in seafood), soil (pica and geophagy), paint (e.g. lead, Pb) and inhalation of contaminated soil and dust (Basta et al., 2001). Ecological exposures include soil ingestion by soil dwelling invertebrates (Rabitsch, 1996) and vertebrates (Bench et al., 2001), and by feeding on plants grown in contaminated soils (Merrington et al., 1997).

United States Environmental Protection Agency (USEPA, 1997) survey showed that over 217,000 sites in the United States urgently require remediation from heavy metal contamination. Decades of mining for metals including lead $(\mathrm{Pb})$ and zinc $(\mathrm{Zn})$ ores have resulted in abandoned mine shafts and towering piles that are major sources of water and soil contamination in the environment. Spelter, WV (Harrison County) is the site of a former Zn smelting plant (Figure 1-1). Improper disposal of wastes and byproducts have resulted in pile of approximately 20 ha, ranging in depth from $0 \mathrm{~m}$ at the margins to 30 $\mathrm{m}$ at the deepest point (Figure 1-2). Located adjacent to the West Fork River, material from the pile has 
contaminated residential soils, including a playground, the river, and its sediments with $\mathrm{Zn}, \mathrm{Pb}, \mathrm{Cd}, \mathrm{Cu}$ and other metal contaminants of concern (Table 1-1). It has been reported from recent ecotoxicology studies that there is increased in $\mathrm{Pb}, \mathrm{Cd}$ and $\mathrm{Zn}$ in fish, birds, and mammals living in or near similar sites (Hensley et al., 2004). Unpublished data (Roy, 2005) using these soils showed a clear trend to increase plant tissue concentrations of $\mathrm{Zn}, \mathrm{Pb}, \mathrm{Cd}$ and $\mathrm{Cu}$ in radish (Rapahanus sativus L.) var. Cherry Belle; carrot (Daucus carota L.) var. Sugarsnax; spinach (Spinacia oleracea L.) var. Corvair; lettuce (Lactuca sativa L.) var. Iceberg when cotyledons were compared to dry seeds or seeds that had imbibed contaminated soil solution. If cotyledon tissue concentrations were only from what was initially present in the seed, then concentrations should decrease due to growth-induced dilution. Other unpublished data using the same contaminated soil (McDonald, pers. comm.) suggested a synergistic interaction between $\mathrm{Pb}$ and $\mathrm{Zn}$ uptake. A synergistic effect is when one metal has the ability to enhance the toxicity or uptake of another metal. However, this interaction was speculative. Synergistic effects of metals on plant uptake are poorly understood (Hensley et. al., 2004).

Some metal contaminants like zinc and copper are micronutrients essential for plant growth (Arnon and Stout, 1939). Because plants require these elements at low concentrations, excessive concentrations found in contaminated soils can negatively affect plant growth and other metabolic activities. For example, Zinc toxicity can lead to blockage of xylem elements (Robb et al., 1980), inhibit photosynthesis (Dhir et al., 2008), alteration of electron transport and the capacity of Ribulosebiphosphate carboxylate (rubisco) to fix $\mathrm{CO}_{2}$ (Valentini et al., 1995). Other metals like $\mathrm{Cd}$ and $\mathrm{Pb}$ have no known biological function in plants and can be toxic at low concentrations or accumulate in edible parts in concentrations high enough to be of concern (Roy and McDonald, 2013). The level of accumulation of elements differs between and within species (Baker et al., 2000; Huang et al., 1996).

To respond to metal toxicity, plants have developed mechanisms for detoxification (Figure 1-3), uptake and distribution (Clemens et al., 2002; Hall, 2002; Haydon and Cobbett, 2007). These mechanisms are complex and vary for different plants species. Some plants can grow in soil with high concentrations of heavy metals up to toxic levels (Banuelos et al., 1997; Raskin and Ensley, 2000). Baker et al. $(1989,1990,1994,2000)$ classified plants into three categories: (1) excluders: plants that can grow in metal-contaminated soil and can avoid excessive uptake and transport of metals; (2) hyperaccumulators: plants that can accumulate more than 100 times larger concentrations of metals than normal plants in aerial parts (Brooks et al., 1977); and (3) indicators: plants that can take up and transport metals to the shoot so that internal concentration is proportional to external levels until 
toxicity occurs. Metal uptake by plants depends on many factors like bioavailability of heavy metals, soil pH (Figure 1-4), soil properties, and soil solution speciation of metals (Ali et al. 2013; Bhargava et al., 2012).

Phytoremediation is the use of plants to remove contaminants from the environment, or render them harmless. These contaminants could be organic compounds, or inorganic metal contaminants such as $\mathrm{Zn}, \mathrm{Cd}, \mathrm{Cu}, \mathrm{Pb}$, and Mn (Mueller et al., 1999a). Phytoremediation utilizes physical, chemical, and biological processes to remove, degrade, transform, or stabilize soil metal contaminants (McCutcheon and Schnoor 2003; Alvarez and IIIman 2006). The rate of phytoremediation is directly proportional to the plant growth while the total amount of metal accumulated is proportional to plant biomass production. Useful plants for phytoremediation must possess the following characteristics: fast growth rate, deep and extensive root system, high biomass production, adapt to low nutrient soil condition, tolerance to low $\mathrm{pH}$, tolerance to drought and heat, easy to harvest and hyperaccumulators of a wide range of toxic metals. However this process is generally poorly understood. As of today, there is no ideal plant that meets all these criteria. For example, some plants such as Round-leaved Penny-cress (Thlapsi rotundifolum) which produces low biomass, can hyperaccumulate $\mathrm{Pb}$ in the roots, yet cannot effectively translocate it to the shoots. Others such as maize (Zea mays), which produces high biomass is inefficient in translocating $\mathrm{Pb}$ from the roots to the shoots.

Phytoremediation is basically classified into five types based on the soil-plant-atmosphere continuum; phytostabilization, rhizofiltration, rhizodegradation, phytoaccumulator/phytoextractor, phytovolatilization (Figure 1-6; Tangahu et al., 2011). Phytostabilization is the prevention of leaching, reduction of runoff, erosion control (Berti and Cunningham, 1993). In another words, phytostabilization prevents the movement of metal contaminants off-site. Rhizofiltration is the absorption of metal contaminants in the root tissues. Rhizodegradation, enhanced by the presence of plant roots, is the degradation of contaminants in the root hotspot (rhizosphere) by microbial activity. For example, reduction of metals to insoluble precipitates on their root surfaces (Horne et al., 2000). Phytoextraction, also known as phytoaccumulation, is the uptake of contaminants from soil, or sediments by plant roots and their translocation and accumulation in above ground biomass. Phytoextraction involves accumulation of metals in the plants (mostly shoots), and subsequent shoot biomass harvest (Blaylock and Huang, 2000). Phytovolatilization is the uptake and transpiration of contaminants such as mercury by plants. 
Despite its tremendous potential, phytoremediation has yet to become a widely-adopted commercial technology (slater et al., 2000). The field of phytoremediation is critically limited by the lack of knowledge of basic plant remedial mechanisms, in addition to inadequate understanding of the effect of agronomic practices on these mechanisms. It is important therefore to consider some of the problems that may limit the commercial application of phytoremediation. In 2000, Slater et al. summarized some of these problems as follows: (1) metal bioavailability- plant available/extractable fraction is usually less than the total fraction; (2) biomass - metal phytoextraction depends on biomass production whereas biomass per unit area is fixed; (3) biomass disposal- because metal-rich biomass must be considered as a contaminated material, it does require safe disposal; (4) economic costcommercialization of the technology; (5) time scale- phytoremediation will almost usually take a longer time to yield results compared to conventional (engineering) methods; and (6) multiple metal contamination- a situation where more than one metal of concern contaminates the soil.

Nearly all metal contaminated soils contain more than one metal (Angelone and Bini, 1992). For example, combinations of $\mathrm{Pb}$ and $\mathrm{Zn}$ are common in urban soils. While $\mathrm{Pb}, \mathrm{Zn}, \mathrm{Cd}$ and $\mathrm{Cu}$ are usually found in the vicinity of metallurgic smelters. The economic values of phytoremediation will be limited if it can only remove one metal from the soil leaving other heavy metals in the contaminated soils behind (Kikuchi et al., 2013). To understand the effect of metal interactions in multi-metal contaminated soils, Kikuchi (et al., 2013) carried out two field surveys in Portugal and Poland to determine whether Eucalyptus could remove $\mathrm{Zn}$ and $\mathrm{Pb}$ from an abandoned mine at Sanguinheiro (rich in galena and sphalerite). They reported that although results of the 2 years survey on this site indicated high phytoextraction efficiencies of $\mathrm{Zn}$ but not $\mathrm{Pb}$, also they could not establish clear relationships between leaf chemistry and soil chemistry. However, they offered a useful suggestion that the root system is probably more important than the leaf system in evaluation of phytoremediation efficiency for both field tests. It is well known that metal contaminants must come in contact with the root system for metal uptake. It has also been well established that plants and metals interact in the root environment. However, the chemical and biological mechanisms of heavy metal uptake by plant are largely unknown. The potential for phytoremediation partly depend upon the interactions among soils, contaminants, and plants. Taiz and Zeiger (2010), reported that absorption of heavy metals by roots is controlled by the concentration of other elements in the soil solution. Such interactions may be positively or inversely correlated. Uptake of a heavy metal may either be enhanced or suppressed by the concentration of other elements in the soil. Heavy metals frequently interact strongly with the soil matrix, and soil conditions can largely influence heavy metal availability. 
This interaction is complex and it is affected by a variety of factors such as climatic conditions and soil properties among others. For example, soil solution is nonhomogeneous and the reactions within the soil are complex. Studies suggested that similar transporters that are used for the macronutrients and micronutrients entrance are also used by plants for the heavy metals uptake and that metal storage utilizes subcellular compartments including vacuoles and lignocellulosic cell wall (Marmiroli et. al., 2006).

The basic mechanisms involved in heavy metal uptake are yet to be discovered. Efforts to resolve these phenomena includes analytical techniques (X-ray spectroscopy, scanning electron microscopy, and microanalysis) to provide information on speciation and localization of metals in plant tissue (chemical approach). Other effort has been shifted to a genetic approach in order to understand the molecular basis of the capacity of some plants to hyperaccumulate and store the metals (biological approach). These include identification of genes and proteins involved in tolerance and accumulation and their genetic bases of tolerance and accumulation mostly using genomic and proteomics approaches (Marmiroli et al., 2006).

On human health risks, the Harvard School of Public Medicine has begun extensive research on similar sites. They are not just evaluating $\mathrm{Pb}$ exposure but also the synergistic effects of $\mathrm{Mn}, \mathrm{Cd}$ and other metals that interact in unknown ways (Bellenger et al., 2001). Similar research conducted by Bellenger with a group of 6th graders from Miami, Oklahoma, suggested an exponential effect when $\mathrm{Pb}$ and $\mathrm{Mn}$ are found together (Bellenger et al., 2001).

The overall goal of this research was to improve our understanding of metal uptake interactions by plants growing in multi-metal contaminated soils.

The specific objectives were to

1. Validate the previous observations from our lab that there was an increase in tissue concentrations of $\mathrm{Zn}, \mathrm{Pb}, \mathrm{Cd}$ and $\mathrm{Cu}$ in radish at different growth stages and different organs and to expand the dataset to include agricultural crops; Indian mustard, corn, soybean. (Chapter 2).

2. To determine if there is a synergistic effect for lead and zinc uptake in radish (Chapter 3 ).

There were two requirements for choosing $\mathrm{Pb}$ for the synergistic uptake study: 1) Pb and $\mathrm{Zn}$ are common co-contaminants, 2) experiment required amending soils with one element because the zinc concentration were already elevated (Table 1-1). In addition $\mathrm{Pb}$ was the amended element because demolition, chipping or peeling paint around older buildings will raise the lead and zinc level in the soils 
directly adjacent to the building. Soil can also be contaminated with lead from several other sources industrial sites, leaded fuels, old lead plumbing pipes, or old orchard sites in production when lead arsenate was used as a pesticide. This lead usually accumulates in the upper $20 \mathrm{~cm}$ of the soil and is highly immobile. 


\section{References}

Ali, H., Khan, E., Sajad, M.A., 2013. Review-Phytoremediation of heavy metals-concepts and applications. Chemosphere. 91: 869-881.

Alvarez P.J., Illman, W.A. 2006. Bioremediation and natural attenuation. Environmental science and technology. Process fundamentals and mathematical models. Wiley, Hoboken, NJ.

Angelone, M., Bini, C. 1992. Trace element concentrations in soils and plants of Western Europe. In: Adriano, D.C. (ed.), Biogeochemistry of Trace Metals. pp. 19-60.

Arnon D.I, Stout P.R. 1939. The essentiality of certain elements in minute quantity for plant with special reference to copper. Plant Physiology. 14(2): 371-375.

Baker, A.J.M., Brooks, R.R. 1989. Terrestrial higher plants which hyperaccumulate metallic elements. A review of their distribution, ecology and phytochemistry. Biorecovery. 1: 81-26.

Baker, A.J.M., Walker, P.L. 1990. Ecophysiology of metal uptake by tolerant plants. In: Shaw, A.J. (Ed.), Heavy Metal Tolerance in Plants. CRC Press, Boca Raton, pp. 155-178.

Baker, A.J.M., Reeves, R.D., Hajar, A.S.M. 1994. Heavy metal accumulation and tolerance in British populations of the metallo-phyte Thlaspi caerulescens J. \& C. Press (Brassicaceae). New Phytologist 127: 61-68.

Baker, A.J.M., McGrath, S.P., Reeves R.D. 2000. Metal hyperaccumulator plants: A Review of the ecology and physiology of a biological resource for phytoremediation of metal-polluted soils. In: Terry, N., Banuelos, G., editors. Phytoremediation of Contaminated Soil and Water. Boca Raton: Lewis Publishers pp. 85-108.

Banuelos, G. S., Awa H.A, Mackey B., Wu L., Cook C., Akohoue S., Zambrzuski S. 1997. Selenium-induced growth reduction in Brassica land races considered for phytoremediation. Ecotoxicological Environmental Safety. 36: 282-287.

Basta, N.T., R. Gradwohl, K.L. Snethen, and J.L. Schroder. 2001. Chemical immobilization of lead, zinc, and cadmium in smelter contaminated soils using biosolids and rock phosphate. Journal of Environmental Quality. 30: 1222-1230.

Bhargava, A., Carmona, F.F., Bhargava, M., Srivastava, S., 2012. Approaches for enhanced phytoextraction of heavy metals. Journal of Environmental Management 105: 103-120. 
Bellenger, D.C. 2001. Future directions for neurobehavioral studies of environmental neurotoxicants. Neurotoxicology. 22(5):645-56.

Bench, G. T.M., Carlsen, P.G., Grant. J.S., Wollett, R.E., Martinelli, J.L., Lewis and K.K. Devine. 2001. Olfactory Bulb uptake and determination of biotransfer factors in the California ground squirrel (Spermophilus beecheyi) exposed to manganese and cadmium in environmental habitats. Environmental Science Technology. 35: 270-277.

Berti, W.R. and Cunningham, S.D. 2000. Phytostabilization of metals. In: Raskin, I. and Ensley, B.D., (eds.), Phytoremediation of toxic metals - using plants to clean up the environment. New York: Wiley. pp. 71-88.

Blaylock, M.J., Huang, J.W. 2000. Phytoextraction of metals. In: Raskin, I. and Ensley, B.D. (eds.), Phytoremediation of toxic metals - using plants to clean up the environment. pp. 53-70. New York: Wiley.

Boon, D.Y., Soltanpour P.N. 1992. Cadmium and zinc contamination of Aspen garden soils and vegetation. Journal of Environmental. Quality. 21: 82-86.

Brevik, E.C. 2013. Soils and human health-an overview. In Soils and human health, Brevik, E.C. \& Burgess L.C. (eds). CRC Press: Boca Raton, FL, USA, pp. 29-82.

Brooks, R.R. 1977. Detection of nickeliferous rocks by analysis of herbarium species of indicator plants. Journal of Geochemical Exploration 7: 49-57.

Clemens, S., Palmgren M.G., and Kramer U. 2002. A long way ahead: Understanding and engineering plant metal accumulation. Trends Plant Science. 7: 309-315.

Cobb, G.P., Sands K., Walters M., Wixson B.G., and Dorward-King E. 2000. Accumulation of heavy metals by vegetables grown in mine wastes. Environmental Toxicological Chemistry. 19: 600-605.

Cui, Y.J., Zhu, Y.G., Zhai, R., Huang, Y., Qiu, Y., Liang, J. 2005. Exposure to metal mixtures and human health impacts in a contaminated area in Nanning, China. Environment International 31: 784790.

Dhir B., Sharmila P., Pardha Saradhi P.P. 2008. Photosynthetic performance of Salvinia natans exposed to chromium and zinc rich wastewater. Brazilian Journal of Plant Physiology. 20: 61-70. 
Flowers, G.C. 2005. Heavy metal contamination and zinc smelting in the Spelter, West Virginia area.

Report submitted to Levin, Papantonio, et al., pp. 1-13.

https://d83vcbxs8ojhp.cloudfront.net/pdf/01.pdf

Hall, J.L. 2002. Cellular mechanisms for heavy metal detoxification and tolerance. Journal of Experimental Botany 53: 1-11.

Haydon M.J., Cobbett, C.S. 2007. Transporters of ligands for essential metal ions in plants. New Phytologists 174: 499-506.

Hensley, Kenneth, et al. 2004. Conferences at the Oklahoma Medical Research Foundation. The Journal of Neuroscience.

Horne, A.J. 2000. Phytoremediation by constructed wetlands. In: Phytoremediation of Contaminated Soil and Water. pp. 13-40. Terry, N. and Bañuelos, G., Eds., Lewis, Boca Raton, Florida

Huang J.W., Cunningham S.D. 2001. Lead phytoextraction: species variation in lead uptake and translocation. New Phytologist 134: 75-84.

Khan, S., Cao, Q., Zheng, Y.M., Huang, Y.Z., Zhu, Y.G. 2008. Health risks of heavy metals in contaminated soils and food crops irrigated with wastewater in Beijing, China. Environmental Pollution. 152: 686-692.

Kikuchi, T., Tanaka, S. 2012. Biological removal and recovery of toxic heavy metals in water environment. Critical Review of Environmental Science Technology. 42 (10): 1007-1057.

Lasat, M.M. 2000. The use of plants for the removal of toxic metal from contaminated soil. Am. Ass. For the Advancement of Science and Environmental Science and Engineering Fellow. pp. 5-24.

Marmiroli N., Marmiroli M., Maestri E., 2006. Phytoremediation and phytotechnologies: a review for the present and the future. In: Soil and water pollution monitoring, protection and remediation. Twardowska I. et al. (eds), Springer. pp. 403-416.

McCutcheon, S.C., Schnoor, J.L. 2003. Phytoremediation. Transformation and control of contaminants. Wiley Interscience, Hoboken, NJ.

Meagher, R.B. 2000. Phytoremediation of toxic elemental and organic pollutants. Current Opinion Plant Biology 3: 153-162. 
Merrington, G., Winder I., Green I. 1997. The uptake of cadmium and zinc by the bird-cherry oat aphid Rhopalosiphum padi (Homoptera: Aphididae) feeding on wheat grown on sewage sludge amended agricultural soil. Environmental Pollution. 114: 111-114.

Pierzynski, G.M., Sims. J.T., Vance, G.F. 2005. Soils and Environmental Quality 3rd ed. CRC Press. Boca Raton, FL, USA. Pp. 569.

Patra, R.C, Amiya K.R., Swarup, D. 2011. Oxidative Stress in Lead and Cadmium Toxicity and Its Amelioration. Vet Med Int. 2011; 457327.

Polomski, R. 2007. The South Carolina Master Gardener Training Manual, Clemson Extension EC 678. pp. 812.

Rabitsch, W.B. 1996. Metal accumulation in terrestrial pulmonates at a lead/zinc smelter site in Arnoldstein, Austria. Bull. Environmental Contamination Toxicology. 56: 734-741.

Raskin, I., Ensley B.D. 2000. Phytoremediation of Toxic Metals: Using plants to clean up the environment. John Wiley and Sons, New York. pp. 303.

Robb, J., Busch, L., Rauser, W. E. 1980. Zinc toxicity and xylem vessel alterations in white beans. Annals of Botany 46: 43-50.

Roy, M., McDonald, L.M. 2013. Metal uptake in plants and health risk assessments in metal contaminated smelter soils. Land Degradation \& Development. DOI: 10.1002/Idr.2237.

Roy, M. 2005. Dissertation submitted to the Davis College of Agriculture, Natural Resources and Design at West Virginia University in partial fulfillment of the requirements for the degree of Doctor of Philosophy in Agricultural Sciences. West Virginia University, Morgantown, West Virginia.

Tangahu B.V., Abdullah, SRS, Basri, H., Idris M., Anuar N., Mukhlisin M. 2011. Review on heavy metals ( $\mathrm{As}, \mathrm{Pb}$, and $\mathrm{Hg}$ ) uptake by plants through phytoremediation. International Journal Chemical Engineering. 21: 1-31.

Thompson E.S., Pick F.R., Bendell-Young L.I. 1997. The accumulation of cadmium by the yellow pond lily, Nuphar variegatum in Ontario peatlands. Arch Environ Contamination Toxicology 32: 161-165.

Taiz, L., Zeiger, E. 2010. Plant Physiology, 5th Edition. Sinauer Inc., Mass. USA. 
United States Environmental Protection Agency (USEPA). 1997. Cleaning up the nation's waste sites: markets and technology trends, EPA 542-R-96-005. Office of Solid Waste and Emergency Response, Washington, DC.

Valentini R., Epron D., Angelis P., Matteucci G., Dreyer E. 1995. In situ estimation of net $\mathrm{CO}_{2}$ assimilation, photosynthetic electron flow and photorespiration in Turkey oak (Quercus cerris L.) leaves: diurnal cycles under different levels of water supply. Plant, Cell \& Environment 18: 631-640.

Watanabe M.E. 1997. Phytoremediation on the brink of commercialization. Environmental Science and Technology 31: 182-6.

Xiong Z.T. 1998. Lead uptake and effects on seed germination and plant growth of a $\mathrm{Pb}$ accumulator, Brassica pekinensis Rupr. Bulletin of Environmental Contamination and Toxicology 60:285-91. 
Table 1-1 Average concentrations and ranges for selected metals in uncontaminated soils (KabataPendias, 2011) and contaminated soil from Spelter, WV.

\begin{tabular}{lccc}
\hline Metal & Average Concentration & Concentration Range & Spelter Soil $^{1}$ \\
\hline $\mathrm{Zn}$ & 65 & $20-770$ & 8600 \\
$\mathrm{~Pb}$ & 23 & $8-70$ & 850 \\
$\mathrm{Cu}$ & 24 & $6.5-140$ & 200 \\
$\mathrm{Cd}$ & 0.44 & $0.18-0.71$ & 96 \\
\hline
\end{tabular}

${ }^{1}$ Roy et al., 2011. 




Figure 1-1 Google: Aerial view of Spelter, WV, and the Spelter waste pile in November 2015 




Figure 1-2 View of the waste pile in Spelter, WV ca 1989 from the banks of the West Fork River. (Courtesy of H. Edenburn) 


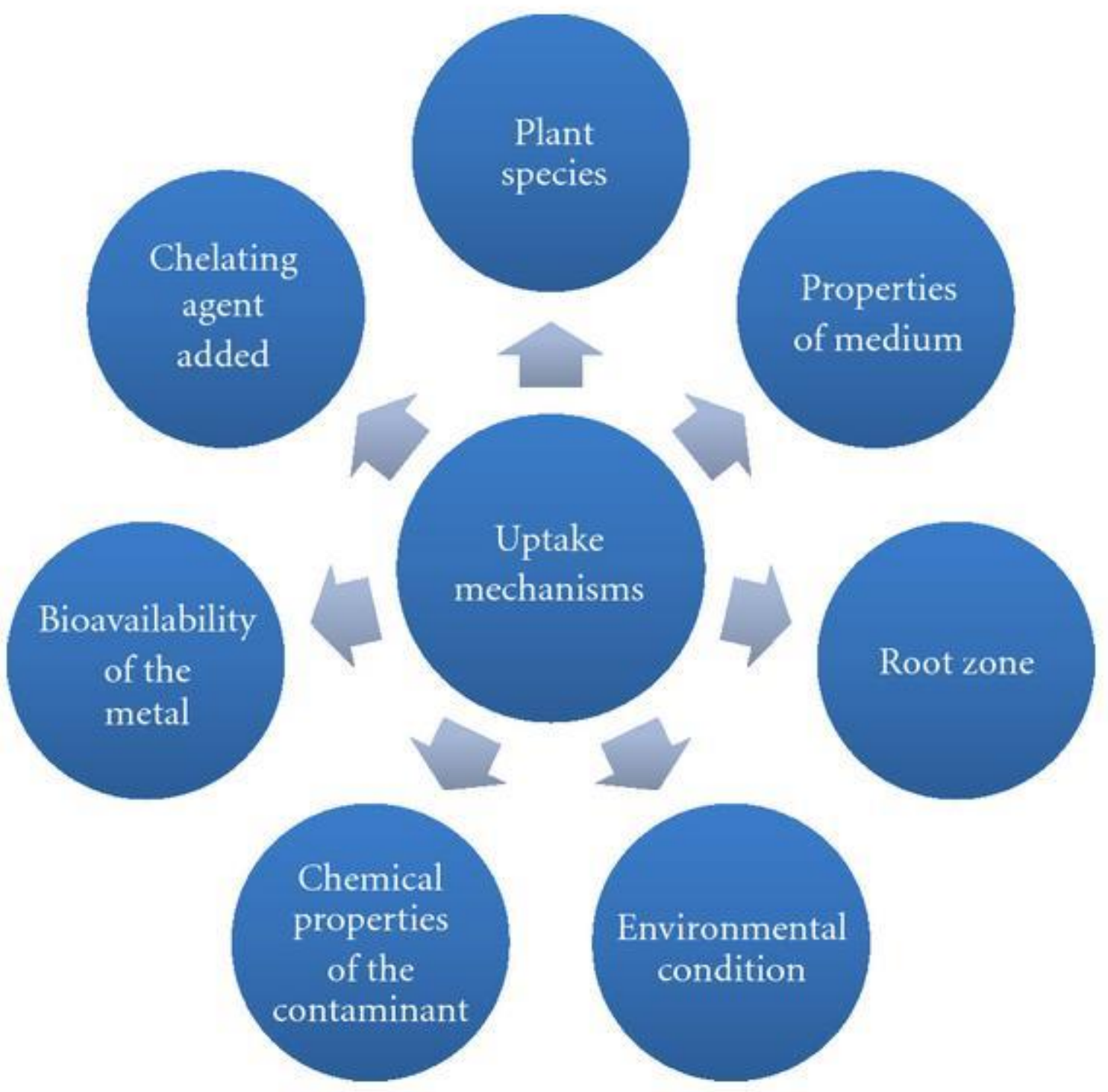

Figure 1-3 Factors that affect the uptake of heavy metals (Tangahu et. al., 2011). 


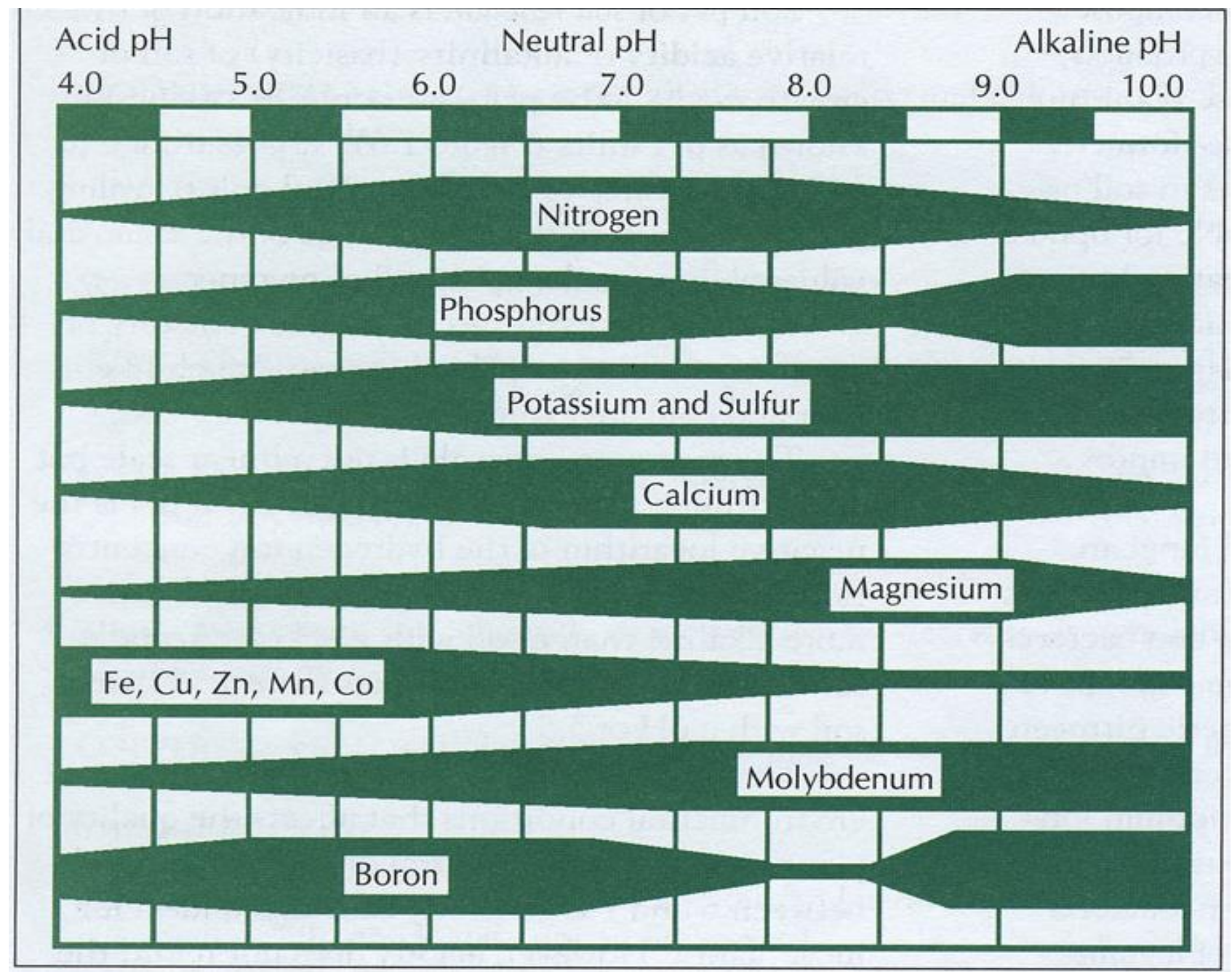

Figure 1-4 Effects of soil pH on nutrient availability (Polomski, 2007). 


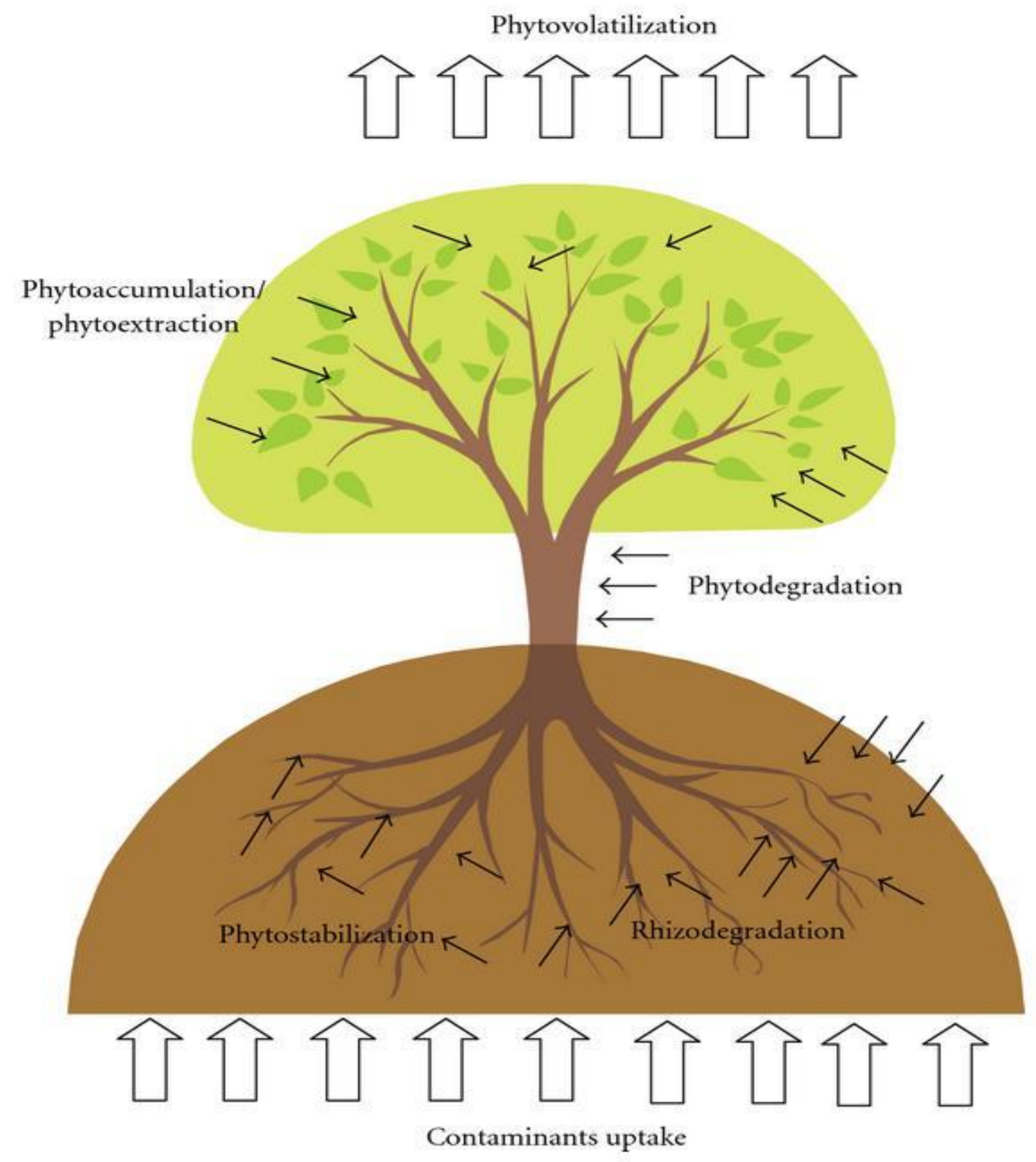

Figure 1-5 The mechanisms of heavy metals uptake by plant through phytoremediation technology (Tangahu et al., 2011). 


\section{Metal Uptake by Radish, Indian mustard, Corn and Soybean from a Multi-metal Contaminated Soil:}

\subsection{Introduction}

Metal pollution can result in severe soil contamination. Any heavy metal may be regarded as a contaminant if it occurs in an unwanted area or in a form or concentration that causes a detrimental effect to humans, plants and animals, or the environment (Verkleij and Prast 1990; Yang et al. 2002). Major sources of this pollution include residues from mining and the smelting industry (Boon and Soltanpour, 1992; Cobb et al., 2000), municipal waste incinerators, burning of fossil fuels (including car exhausts), lead-based paint and the use of sludge or urban composts, pesticides and fertilizers. Several studies have been done on heavy metal/metalloid accumulation in plants. Reports from these studies have shown that these elements are hazardous to humans, plants, animals or the environment. However, $\mathrm{Zn}$ and $\mathrm{Cu}$ are micronutrients essential for plant growth (Arnon and Stout, 1939). Because plants require these elements at low concentrations, excessive concentrations found in contaminated soils can negatively affect plant growth and other metabolic activities. For example, Zinc toxicity can lead to blockage of xylem elements (Robb et al., 1980), inhibition of photosynthesis (Dhir et al., 2008), alteration of electron transport and the capacity of rubisco to fix $\mathrm{CO}_{2}$ (Valentini et al., 1995). Other metals like cadmium and lead have no known biological function in plants and can be toxic at low concentrations or accumulate in edible parts in concentrations high enough to be of concern. (Roy and McDonald, 2013). The level of accumulation of elements differs between and within species. The distribution and occurrence of heavy metals in agricultural soil is a subject of major concern and has attracted a number of studies (e.g Muller and Anke 1994; Sanchez-Camazano et al. 1994; Cui et al., 2004). For example, approximately fifty percent of human $\mathrm{Pb}$ intake is from food, with plants contributing about half of this. (Nasreddine and Parent-Massin, 2002).

Over the years, lead and cadmium have been the elements of most concern because of their potential accumulation or toxicity. According to the Environmental Protection Agency (EPA), lead is the most abundant metal pollutant in the environment (Watanabe et al., 1997). Important agricultural crops such as spinach, lettuce, carrot, radish, have been shown to accumulate heavy metals, e.g. $\mathrm{Cd}, \mathrm{Cu}, \mathrm{Mn}$, $\mathrm{Pb}$ and $\mathrm{Zn}$ in their tissues (Muller and Anke, 1994; Bahemuka and Mubofu 1999; Cobb et al., 2000). And it has been well established that metal uptake increases in plants that are grown in areas with increased soil contamination. Among these heavy metals, $\mathrm{Cd}$ and $\mathrm{Zn}$ are fairly soluble and mobile which allow 
them to be easily absorbed by plants (Mench et al. 1994). On the other hand, $\mathrm{Cu}$ and $\mathrm{Pb}$ are strongly adsorbed onto soil particles and organic matter, thus reducing their bioavailability to plants. Root to shoot metal translocation is an important physiological process because it is much simpler to harvest shoots than roots (Zacchini et al. 2009; Tangahu et al. 2011; Ali et al. 2013).

Baker et al. (1989, 1990, 1994, 2000) classified plants into three different categories: (1) excluders: plants that can grow in metal-contaminated soil and can avoid excessive uptake and transport of metals; (2) hyperaccumulators: plants that can accumulate more than 100 times larger concentrations of metals than normal plants in aerial part (Brooks et al., 1977); and (3) indicators: plants that can uptake and transport metals to the shoot so that internal concentration is proportional to external levels until toxicity occurs. Generally, hyperaccumulators refer to plants able to accumulate $>0.1 \%$ of dry weight of elements such as $\mathrm{Ni}$, Co or $\mathrm{Pb}$. For $\mathrm{Zn}$ the limit is $>1 \%$, and for $\mathrm{Cd}>0.01 \%$ of dry weight.

Studies have shown that high levels of heavy metals in soil usually result in greater heavy metal uptake by plants. For example, Van Nevel et al. (2007) enumerated three major risks associated with metal accumulation in aboveground plant parts: (1) metals entering the food chain through herbivores, (2) dispersion and transport of contaminated plant material to adjacent environments, and (3) potential accumulation of metals in the topsoil. Topsoil in particular is very vulnerable and sensitive to metal contaminations because this is where most biological activity occurs (Van Nevel et al. 2007).

Despite the fact about 500 species have been documented to accumulate heavy metals including $\mathrm{As}, \mathrm{Cd}, \mathrm{Co}, \mathrm{Cu}, \mathrm{Mn}, \mathrm{Ni}, \mathrm{Pb}, \mathrm{Sb}, \mathrm{Se}, \mathrm{Tl}, \mathrm{Zn}$, hyperaccumulators account for less than $0.2 \%$ of all known species (Rascio and Navari-Izzo, 2011) with many yet to be discovered. For example, to date, only five hyperaccumulators of $\mathrm{Pb}$ (Armeria martima, Thlaspi rotundifolium, Thlaspi alpestre, Alyssum wulfenianum, Polycarpaea synandra) and one hyperaccumulator each for $\mathrm{Cd}$ and $\mathrm{As}$ have also been identified. About $25 \%$ of these metal accumulators belong to the family Brassicaceae (Raskin et al., 1994; Rascio and Navari- Izzo 2011).

Spelter, WV (Harrison County) is the site of a former Zn smelting plant. Improper disposal of wastes and by products resulted in pile of approximately $20 \mathrm{ha}$, ranging in depth from $0 \mathrm{~m}$ at the margins to $30 \mathrm{~m}$ at the deepest point. Located adjacent to the West Fork River, material from the pile has contaminated residential soils, including a playground, the river, and its sediments with $\mathrm{Zn}, \mathrm{Pb}, \mathrm{Cd}$, $\mathrm{Cu}$ and other metal contaminants of concern (Flowers, 2005; Roy and McDonald, 2013). Unpublished 
data (Roy and McDonald, pers. comm.) using these soils showed a clear trend to increase tissue concentrations of $\mathrm{Zn}, \mathrm{Pb}, \mathrm{Cd}$ and $\mathrm{Cu}$ in cotyledons compared to dry seeds or seeds that had imbibed contaminated soil solution. If cotyledon tissue concentrations were only from what was initially present in the seed then concentrations should decrease due to growth-induced dilution.

The overall goal of this research was to improve our understanding of metal uptake by important agricultural crops growing in metal contaminated soils. Unlike previous studies from our lab which used only dicotyledonous vegetable plants, this study expands the data to include a monocotyledonous plant with endosperm (Zea mays, corn).

The specific objective was to determine the concentrations of $\mathrm{Cd}, \mathrm{Cu}, \mathrm{Zn}, \mathrm{Pb}$, and $\mathrm{Mn}$ in Radish, Indian mustard, Corn and Soybean and to compare the potential of these four species to accumulate these metal elements from imbibition to development of true leaves.

\subsection{Material and Methods}

\subsubsection{Soil Sampling and Characterization}

Contaminated soil for this study was collected near Hephzibah in Harrison County WV about 200 $\mathrm{m}$ from the edge of the Spelter waste pile on a terrace that had been mapped as urban land. Collected soil samples from this site were brought to the WVU greenhouse, air dried, screened through a 2-mm sieve, and stored in plastic bags. Soil $\mathrm{pH}$ was determined in distilled deionized water (1:1) using an electrode. Extractable ( $\mathrm{Cd}, \mathrm{Cu}, \mathrm{Pb}, \mathrm{Mn}$ and P) were determined with Mehlich 3 procedure (NEC, 2012). The standard (NBS 1512 Orchard Leaf) was included for every plant tissue determination. All metal concentrations were determined by ICP-OES (Perkin-Elmer Optima DV2100, Perkin Elmer Corp., Norwalk, CT.) Total carbon and nitrogen were determined by dry combustion (LECO TruSpec CHN analyzer, LECO Corp. St. Joseph, MI). All determinations were made in at least duplicate.

\subsubsection{Plant species}

To provide overlap with previously conducted research in our laboratory, radish (Raphinus sativus var. Cheriette) was also used in this study. Note that the variety previously used 'Cherry Belle' is no longer available. The following agronomic crops, as important components of human diet, were also used Indian mustard (Brassica juncea var. Mighty Mustard), a known metal accumulator; and a monocotyledonous plant- large seeded species corn (Zea mays var. Luscious, Hybrid Bicolor); and a leguminous plant soybean (Glycine max var. Butterbean). 


\subsubsection{Experiment I}

Seeds were sown on contaminated soil placed in large plastic petri dishes (60 mm x15 mm) containing 100g of metal contaminated soil and brought to approximate field capacity. For the purpose of this experiment, cotyledons (Figure 2-9 to 2-10) were defined as the leaf-like structure (not green) formed prior to emergence of the first true leaf. Opening of the seed coat was used as evidence of seed germination. Thus, before germination, hydrated seeds (Figure 2-8) were collected from petri dishes after 12 hours for radish and Indian mustard, and after 2 days for soybean and corn. Because there was a very short period between germination and cotyledon emergence through first true leaves, radish and Indian mustard cotyledons were harvested after 24 hours. Soybean cotyledons and remains of corn endosperm were also harvested after 10 days following germination. The soybean seed coat was separated from the cotyledons manually (Figure 2-11). Zinc, $\mathrm{Mn}, \mathrm{Pb}, \mathrm{Cd}$ and $\mathrm{Cu}$ tissue concentrations (dry weight basis) were determined on dry seeds, hydrated seeds, cotyledons (Figure 2-8 to 2-11) and. There were three replicates for each radish, Indian mustard, corn, and soybean with duplicate subsamples for metal determinations. Because the seed sizes were different for each species, sufficient seeds per petri dish were used throughout this experiment for each specific petri dish. Analysis of variance (ANOVA) was used to determine significant differences for interactions $(\alpha=0.05)$.

\subsubsection{Experiment II}

Plastic sample pots $(15.24 \mathrm{~cm})$ with $1 \mathrm{~kg}$ of Spelter soil were used to grow radish, Indian mustard, corn and soybean in triplicate (twelve pots). To prevent loss of nutrients and trace elements out of the pots, soil water content was maintained by manual daily watering, as needed. Sufficient seeds with three replicates were used for each species of plants as described above. The study was conducted in an uncontrolled greenhouse with manual wetting to near field capacity daily-pots were watered daily to approximate field capacity ( never saturated nor drainage). The control for this study was greenhouse media (Sunshine Gro Mix, LC1, Sun Gro Horticulture Canada Ltd.) with the following composition: 7383\% Canadian Sphagnum Peat Moss, 17-27\% Perlite, and lime. All potted plants for the control were fertilized with 150 ppm of fertilizer (10-10-20) about three times a week. Manual wetting normally followed fertilizer application at 24 hour intervals. Twelve pots, three replicates were used for the control; a total of 24 pots were used for the whole uptake experiment.

Plants were harvested after eight weeks. The harvested plants were thoroughly rinsed with DDI water to remove soil/medium; roots, stems, and leaves were separated. The roots were immersed into 
$0.01 \mathrm{M} \mathrm{Na}_{2}$-EDTA (for 30 minutes) to remove extracellular metals and soil particles adhering to the root surface due to long term direct contact with the soil (Slaveykova and Wilkinson, 2002; Yang et al. 2002). The plant sample digestion was carried out by dry ashing in a muffle furnace overnight at $550^{\circ} \mathrm{C}$. Ashed material was dissolved with a few drops of $10 \%$ nitric acid, filtered and diluted to constant volume (25 $\mathrm{mL}$ ). Zinc, $\mathrm{Mn}, \mathrm{Pb}, \mathrm{Cd}$ and $\mathrm{Cu}$ tissue concentrations were determined and reported for roots, stems, and leaves on a dry weight basis as described above. ANOVA was was conducted at $\alpha=0.05$ to compare the means. [The orchard leaf (US Department of Commerce and National Bureau of standards, Office of Standard Reference Material, Washington, D.C. 20234; NBS Standard Reference Material)] was included as representative of plant material and it was used for quality control for all ICP-OES results. The behavior exhibited by the plants grown on the contaminated were visually noted throughout the experimental period. This was compared to the control plants grown on greenhouse media. Yellowing of leaves, stunted growth and other visual color differences were noted in the course of the study and were attributed to metal contaminant toxicity in the contaminated soils.

\subsection{Results and Discussion}

\subsubsection{Soil Properties}

Although mapped as Urban Land the collected soil was likely from the Lindside series given its landscape landscape position and nearby mapped soils. Soils were acidic (Table 2-1) with some differences by species and pot which will be discussed below. Mehlich 3 extractable metal ( $\mathrm{Cu}, \mathrm{Zn}$, and $\mathrm{Mn}$ ) concentrations were well above the adequate requirement for optimum plant growth, as was extractable $\mathrm{P}$ ( 
Table 2-2). Total concentrations of $\mathrm{Cd}, \mathrm{Cu}, \mathrm{Pb}$ and $\mathrm{Zn}$ were also large and above the average range (Table 2-3). The measured total C of $2.9 \%$ (Table $2-3$ ) likely does not indicate soil organic $\mathrm{C}$ but is an artifact of the dry combustion technique that does not distinguish between carbon forms.

\subsubsection{Tissue Concentrations}

\subsubsection{A. Cadmium}

No Cd was detected in the dry seeds for any of the plants species (Figure 2-1A). There was a significant increase in $\mathrm{Cd}$ concentrations for all species as growth progressed to hydrated seed and cotyledon (Figure 2-1A). Similar results were found by Roy (2005) except in the present study cotyledons were harvested earlier than in Roy (2005). Except for radish, there was a trend for tissue concentrations to increase from roots to stems to leaves as plant grew from dry seeds to whole plants, especially for soybean (Figure 2-1B). The highest Cd concentration was observed in radish root and were statistically significant when compared to, Indian mustard, corn, and soybean. Whereas for radish, Cd concentration was highest in the root. Radish is known to accumulate metals in the below ground expanded hypocotyls (Massaccesi et. al., 2014). Cadmium concentrations Indian mustard, corn, and soybean leaves were higher than in their roots, stems, cotyledons, hydrated seeds and dry seeds; and were not statistically significant for each plant part except for radish root). Cadmium concentrations were below 2 $\mathrm{mg} \mathrm{kg-}^{-1}$ for all the species; however above the threshold concentration of $0.003 \mathrm{mg} \mathrm{kg}^{-1}$ (FAO, 2001). Roots, stems and leaves tissue $\mathrm{Cd}$ concentrations were higher in the contaminated soil than in the greenhouse mix control (Appendix, Figure2-12).

\subsubsection{B. Copper}

For the four species, the greatest amounts of Cu uptake occurred in soybean (Figure 2-2A \& 2B); dry seeds $\left(12.55 \mathrm{mg} \mathrm{kg}^{-1}\right)$, hydrated seeds $\left(14.48 \mathrm{mg} \mathrm{kg}^{-1}\right)$, cotyledons $\left(11.72 \mathrm{mg} \mathrm{kg}^{-1}\right)$, roots (41.29 mg 
$\mathrm{kg}^{-1}$ ) and leaves $\left(19.72 \mathrm{mg} \mathrm{kg}^{-1}\right)$, of soybean, except for India mustard stems $\left(48.73 \mathrm{mg} \mathrm{kg}^{-1}\right)$, where Cu uptake was higher when compared to soybean. Lowest $\mathrm{Cu}$ uptake was found in monocot species-corn. Lower $\mathrm{Cu}$ contents were found in radish $\left(3.5 \mathrm{mg} \mathrm{kg}^{-1}\right)$, and corn $\left(2.15 \mathrm{mg} \mathrm{kg}^{-1}\right)$ dry seeds respectively, except for Indian mustard $\left(7.6 \mathrm{mg} \mathrm{kg}^{-1}\right)$, and soybean $\left(12.5 \mathrm{mg} \mathrm{kg}^{-1}\right)$, However, there was a pattern of increasing $\mathrm{Cu}$ concentrations for all species as plant grows from dry seeds to whole plants (roots, stems, and leaves). $\mathrm{Cu}$ concentration was most in roots for all species and least in leaves.

\subsubsection{Zinc}

From Figure 2-3A \& 3B, highest zinc uptake for the four species was recorded for Indian mustard dry seeds (62.4 mg kg-1); hydrated seeds (111.3 mg kg-1); stems (3647.5 mg kg-1); leaves (2634.4 $\mathrm{mg} \mathrm{kg}^{-1}$ ). Corn cotyledons $\left(235.3 \mathrm{mg} \mathrm{kg}^{-1}\right)$ and radish roots $\left(1061.3 \mathrm{mg} \mathrm{kg}^{-1}\right)$ also had the high $\mathrm{Zn}$ uptake. This correlates with other studies which accentuated that Brassicae species is one of the major promising heavy metal accumulators. However, $\mathrm{Zn}$ tissue concentrations in Indian mustard were not different from radish and this could be because both Indian mustard and radish belong to the same familyBrassicaceae. Indian mustard and radish have higher potential for $\mathrm{Zn}$ uptake, followed by leguminoussoybean and the lowest for monocot- corn.

\subsubsection{Lead}

For the four species under study, lead concentrations was lower in hydrated seeds and cotyledons (except for Indian mustard cotyledons-8.0 mg kg- ${ }^{1}$ and it was statistically significant) (Figure 2-4A \& 2-4B). Lead contents in dry seeds were below detection limits. However $\mathrm{Pb}$ uptake was higher for Indian mustard $\left(24.7 \mathrm{mg} \mathrm{kg-}^{-1}\right)$ and soybean (30. $\left.\mathrm{mg} \mathrm{kg-}^{-1}\right)$ roots and lower for radish $\left(7.0 \mathrm{mg} \mathrm{kg-}{ }^{-1}\right)$ and corn (6.2 $\mathrm{mg} \mathrm{kg-}^{-1}$ ) roots. For stems, Indian mustard Pb content (48.0 $\mathrm{mg} \mathrm{kg-}^{-1}$ ) was statistically significant compared to corn (3.2 $\left.\mathrm{mg} \mathrm{kg-}^{-1}\right)$ soybean $\left(5.5 \mathrm{mg} \mathrm{kg}^{-1}\right)$ but was not statistically different for radish stem (22.4 $\left.\mathrm{mg} \mathrm{kg-}^{-1}\right)$. Similarly, Indian mustard had the highest Pb uptake in leaf $\left(22.0 \mathrm{mg} \mathrm{kg-}^{-1}\right)$ and it was statistically significant for radish (3.0 $\left.\mathrm{mg} \mathrm{kg-}^{-1}\right)$, corn $\left(1.2 \mathrm{mg} \mathrm{kg}^{-1}\right)$ except soybean $\left(6.3 \mathrm{mg} \mathrm{kg-}{ }^{-1}\right)$. Despite that soybean root $\left(30.8 \mathrm{mg} \mathrm{kg}^{-1}\right)$ had the highest $\mathrm{Pb}$ uptake in the root of the four species, the amount of $\mathrm{Pb}$ translocated to the stem and leaf was among the lowest. Monocot species-corn has lowest affinity for $\mathrm{Pb}$ uptake compared to the other species. This is in agreement with study by Roongtanakiat and Chairoj (2002) that only a fraction of $\mathrm{Pb}$ translocated to the shoot while studying uptake potential of $\mathrm{Pb}$ by Vetiveria zizanioides (ecotype Suratthani) reported measured $\mathrm{Pb}$. This is probably due to difficulty in $\mathrm{Pb}$ translocation to above the ground tissues. 


\subsubsection{E. Manganese}

Manganese behavior was highly unpredictable (Figure 2-5A \& 2-5B) and we suggested this is due to low $\mathrm{pH}$ of the soil (Table 2-1). One of the characteristics of a good hyperaccumulator/accumulator is that they must be able to tolerate a low pH or acid condition. For the four species, Mn concentration was lower for both dry seeds (Figure 2-5A) and roots (Figure 2-5B). However, there was no clear trends for $\mathrm{Mn}$ accumulation in hydrated seed, cotyledon, stem and leaf (Figure 2-2A \& 2-2B).

The first report for the presence of Mn toxicity on contaminated soil from this site was discovered in the course of this particular study. Previous study from our lab focused on only four metals- $\mathrm{Cd}, \mathrm{Cu}, \mathrm{Pb}, \mathrm{Zn}$. However in this study, marginal leaf chlorosis was observed for the leguminous species-soybean (Figure 2-6). Further analysis of $\mathrm{pH}$ for each species in contrast to random average samples for $\mathrm{pH}$ showed that mean soil pH was 5.36, 5.06, 5.05, and 4.91 (Table 2-1) for radish, Indian mustard, corn and soybean, respectively. Manganese behavior is complex and unpredictable at $\mathrm{pH}<5.5$ (too available to plants and thus toxic). Mn known to be to be available in excess to leguminous species at this $\mathrm{pH}$ range because of its toxicity (Eun et al., 2010). Further literature review also revealed that all leguminous plants are generally sensitive to $\mathrm{Mn}$ toxicity and the symptoms of which is marginal leaf chlorosis. This was validated by control soybean on greenhouse mix with no contaminants present. The control soybean exhibited no symptoms of leaf chlorosis (Figure 2-7). Stunted, crinkled, "puckering" or raised areas in leaves chlorotic and marginal leaves chlorosis are symptoms of $\mathrm{Mn}$ toxicity in soybeans (Schultz et al., 1999). For a given soil condition (soil temperature and moisture), Mn toxicity or deficiency depends on soil pH because Mn deficiency cannot occur in acidic soil (Spelter soil) with $\mathrm{pH}<6.0$, the observed $\mathrm{Mn}$ behavior must have been Mn toxicity.

No linear relationship could be established as we moved from dry seeds, to hydrated seeds, to cotyledons, to whole plants (roots, stems, leaves). Mn concentrations varied within plants part and also among the four species.

\subsection{Discussion}

The dicots; radish, Indian mustard, and soybean showed a higher potential for metal uptake and accumulation compared to monocot, corn. However this conclusion is speculative because only one monocot and three dicot species were used for this study, so further study is needed. Zinc concentrations were relatively higher, richly mobilized, and readily translocated within the plant tissues. Also $\mathrm{Zn}$ tended to accumulate more in the stem than in the leaf is probably due to its high mobility 
within the plant tissues. Among the four species, soybean roots had the highest Pb uptake but could not be translocated to the stems or leaves which is in agreement with other studies in that $\mathrm{Pb}$ uptake is restricted to the root regions with little translocation (Peralta-Videa et al., 2009). In contrast, radish and Indian mustard had the highest translocation of $\mathrm{Pb}$ to stems and leaves, whereas corn has lowest $\mathrm{Pb}$ accumulation or translocation.

Radish organs tended to accumulate $\mathrm{Cd}$ more than any other species from hydrated seeds to cotyledon to root to stem to leaf (Figure 2-1). For all species, in contrast, Cu was accumulated more in the roots than any other plant organs. The most readily accumulated heavy metals from this soil were in this order; $\mathrm{Zn}>\mathrm{Mn}>\mathrm{Cu}>\mathrm{Pb}>\mathrm{Cd}$. Cadmium ( $\mathrm{Cd}$ ), concentrations in this study were low but above guidance level and thus, can contribute to the total body burden of $\mathrm{Cd}$.

At eight weeks, results of tissue concentration of $\mathrm{Cd}$ (Figure 3-7), $\mathrm{Cu}$ (Figure 3-8), Pb (Figure 3-9), Zn (Figure 3-10), and Mn (Figure 3-11) from contaminated soil were relatively higher compared to uncontaminated greenhouse mix. High metal concentrations in the plants tissues were attributed to the presence of these metal contaminants has been previously (Roy et al., 2011; Table 2-1).

Overall, our study demonstrated that there was an observable trend for tissue $\mathrm{Zn}, \mathrm{Pb}, \mathrm{Cu}, \mathrm{Cd}$ concentrations to increase starting from seed imbibition, to cotyledon, to whole plants; except for $\mathrm{Mn}$. where that there was no clear trend noted. Also this study established that heavy metal uptake was not only metal specific but also species specific. When we compared results for soybean (Glycine max) with corn (Zea mays) we determined that, soybean removed more metal and thus a better accumulator of metals. Interestingly, the two members of the family Brassicaceae-radish and Indian mustard had similar efficiency to accumulate metals in multi-contaminated soils. This study also showed that heavy metal has a significant effect on plant growth on contaminated soil. 


\section{References}

Ali, H., Khan, E., Sajad, M.A., 2013. Review-Phytoremediation of heavy metals-concepts and applications. Chemosphere. 91: 869-881.

Arnon D.I, Stout P.R. 1939. The essentiality of certain elements in minute quantity for plant with special reference to copper. Plant Physiology. 14(2): 371-375.

Bahemuka, T.E., Mubofu, E.B. 1999. Heavy metals in edible green vegetables grown along the sites of the Sinza and Msimbazi rivers in Dar es Salaam, Tanzania. Food Chemistry 66: 63-66.

Baker, A.J.M., Brooks, R.R. 1989. Terrestrial higher plants which hyperaccumulate metallic elements. A review of their distribution, ecology and phytochemistry. Biorecovery 1: 81-26.

Baker, A.J.M., Walker, P.L. 1990. Ecophysiology of metal uptake by tolerant plants. In: Shaw, A.J. (Ed.), Heavy Metal Tolerance in Plants. CRC Press, Boca Raton, pp. 155-178.

Baker, A.J.M., Reeves, R.D., Hajar, A.S.M. 1994. Heavy metal accumulation and tolerance in British populations of the metallo-phyte Thlaspi caerulescens J. \& C. Press (Brassicaceae). New Phytologist 127: 61-68.

Baker, A.J.M., McGrath, S.P., Reeves R.D. 2000. Metal hyperaccumulator plants: A Review of the ecology and physiology of a biological resource for phytoremediation of metal-polluted Soils. In: Terry, N., Banuelos, G., editors. Phytoremediation of Contaminated Soil and Water. Boca Raton: Lewis Publisher's pp. 85-108.

Boon, D.Y., Soltanpour P.N. 1992. Cadmium and zinc contamination of Aspen garden soils and vegetation. Journal of Environmental. Quality. 21: 82-86.

Brooks, R.R. 1977. Detection of nickeliferous rocks by analysis of herbarium species of indicator plants. Journal of Geochemical Exploration 7: 49-57.Clemens, S., Palmgren M.G., and Kramer U. 2002. A long way ahead: Understanding and engineering plant metal accumulation. Trends Plant Science. 7: 309-315.

Cobb, G.P., Sands K., Walters M., Wixson B.G., and Dorward-King E. 2000. Accumulation of heavy metals by vegetables grown in mine wastes. Environmental Toxicological Chemistry. 19: 600-605.

Cui, Y.J., Zhu, Y.G., Zhai, R., Huang, Y., Qiu, Y., Liang, J. 2005. Exposure to metal mixtures and human health impacts in a contaminated area in Nanning, China. Environment International 31: 784790. 
Dhir B., Sharmila P., Pardha Saradhi P.P. 2008. Photosynthetic performance of Salvinia natans exposed to chromium and zinc rich wastewater. Brazilian Journal of Plant Physiology. 20: 61-70.

Eun, H. Quirine, K., Murray M. 2010. Cornell University Cooperative Extension. Nutrient management Spear Program: http://nmsp.cals.cornell.edu.

Flowers, G.C. 2005. Heavy metal contamination and zinc smelting in the Spelter, West Virginia area. Report submitted to Levin, Papantonio, et al., pp. 1-13. https://d83vcbxs8ojhp.cloudfront.net/pdf/01.pdf

Intawongse, M. 2007. Uptake of heavy metals by vegetable plants grown on contaminated soils, their bioavailability and speciation: http:nrl.northumbria.ac.uk/385/.

Kabata-Pendias, A. and H. Pendias. 1984. Trace elements in soils and plants. CRC Press, Inc., Boca Raton, LA. 315 pp.

Mench, M., Vangronsveld, J., Didier, V., Clijsters, H. 1994. Evaluating of metal mobility, plant availability and immobilization by chemical agents in a limed-silty soil. Environmental Pollution 86: 279-286.

Muller, M., Anke, M. 1994. Distribution of cadmium in the food chain (soil-plant-human) of a cadmium exposed area and the health risks of the general population. Science of the Total Environment 156: 151-158.

Nasreddine, L., Parent-Massin, D. 2002. Food contamination by metals and pesticides in the European Union. Should we worry? Toxicology Letters 127: 29-41.

NEC. 2012. Recommended Soil Testing Procedures for the Northeastern United States. 2011. Northeast Coordinating Committee for Soil Testing (NEC 2012). Northeastern Regional Publication No. 493 3rd (ed). http://extension.udel.edu/lawngarden/1864-2/lawn-garden/soil-healthcomposting/recommended-soil-testing-procedures-for-the-northeastern-united-states.

Raskin, I., Ensley B.D. 2000. Phytoremediation of Toxic Metals: Using plants to clean up the environment. John Wiley and Sons, New York. pp. 303.

Robb, J., Busch, L., Rauser, W. E. 1980. Zinc toxicity and xylem vessel alterations in white beans. Annals of Botany 46: 43-50.

Roongtanakiat, N., Chairoj, P. 2002. Uptake potential of some heavy metals by vetiver grass. Proceedings of the Second International Conference on Vetiver. Office of the Royal Development 
Projects Board, Bangkok. Pp. 427-429.

Roy, M., McDonald, L.M. 2013. Metal uptake in plants and health risk assessments in metal contaminated smelter soils. Land Degradation \& Development. DOI: 10.1002/ldr.2237.

Roy, M. 2005. Dissertation submitted to the Davis College of Agriculture, Natural Resources and Design at West Virginia University in partial fulfillment of the requirements for the degree of Doctor of Philosophy in Agricultural Sciences. West Virginia University, Morgantown, West Virginia.

Slaveykova, V.I., Wilkinson, K.J. 2002. Physicochemical aspects of lead bioaccumulation by Chlorella vulgaris. Environmental Science and Technology. 36: 969-975.

Schultz, E.E., Kelling, K.A. 1999. Understanding plant nutrients A2526. Soil and Applied Manganese. RP08-2004/SR07/99

Tangahu B.V., Abdullah, SRS, Basri, H., Idris M., Anuar N., Mukhlisin M. 2011. Review on heavy metals $(\mathrm{As}, \mathrm{Pb}$, and $\mathrm{Hg}$ ) uptake by plants through phytoremediation. International Journal Chemical Engineering. 21: 1-31

United States Environmental Protection Agency (USEPA). 1997. Cleaning up the nation's waste sites: markets and technology trends, EPA 542-R-96-005. Office of Solid Waste and Emergency Response, Washington, DC.

Valentini R., Epron D., Angelis P., Matteucci G., Dreyer E. 1995. In situ estimation of net $\mathrm{CO}_{2}$ assimilation, photosynthetic electron flow and photorespiration in Turkey oak (Quercus cerris L.) leaves: diurnal cycles under different levels of water supply. Plant, Cell \& Environment 18: 631-640.

Van Nevel, L., Mertens J., Oorts K., Verheyen K. 2007. Phytoextraction of metals from soils: how far from practice? Environmental Poluution.150: 34-40.

Verkleij, J.A.C., Prast J.E. 1990. Cadmium tolerance and co-tolerance in Silene vulgaris. New Phytologist 111:637-645.

Wang, Y., Ying, Y., Chen, J., Wang, X. 2004. Transgenic Arabidopsis overexpressing Mn-SOD enhanced salt-tolerance. Plant Sci. 167: 671-677.

Watanabe M.E. 1997. Phytoremediation on the brink of commercialization. Environmental Science and Technology 31: 182A-6A. 
Yang, X., Long, X.X., Ni, W.Z., \& Fu, C.X. 2002. Sedum A. H: A new Zn hyperaccumulating plant first found in China. Chin. Science. Bulletin. 47: 1634-1637.

Zacchini M., Pietrini F., Mugnozza G.S., lori V., Pietrosanti L., Massacci A. 2009. Metal tolerance, accumulation and translocation in poplar and willow clones treated with cadmium in hydroponics. Water Air Soil Pollution 197: 23-34. 
Table 2-1 Mean soil pH at the end of the experiment for Radish, Indian mustard, corn and soybean. Initial soil pH was $5.2(n=3)$

\begin{tabular}{cc}
\hline Treatment & Mean $\mathrm{pH}$ \\
\hline Radish & 5.36 \\
Indian mustard & 5.06 \\
Corn & 5.05 \\
Soybean & 4.91 \\
\hline
\end{tabular}


Table 2-2 Mean and standard deviation (St. Dev.) for Mehlich 3 exchangeable fractions for $\mathrm{Cd}, \mathrm{Cu}, \mathrm{Zn}, \mathrm{Pb}, \mathrm{Mn}$, and $\mathrm{P}$ for the Spelter soil $(\mathrm{n}=3)$.

\begin{tabular}{cccc}
\hline Element & Mean & St. Dev. & Adequate \\
\hline $\mathrm{Cd}$ & 2.12 & \pm 0.22 & \\
$\mathrm{Cu}$ & 15.1 & \pm 1.33 & $\mathrm{na}^{1}$ \\
$\mathrm{Zn}$ & 456 & \pm 41.79 & $>1$ \\
$\mathrm{~Pb}$ & 5.25 & \pm 0.99 & $\mathrm{na}$ \\
$\mathrm{Mn}$ & 96.4 & \pm 13.23 & $>1$ \\
$\mathrm{P}$ & 569 & \pm 50.46 & 30 \\
\hline
\end{tabular}

${ }^{1}$ na: not applicable. 
Table 2-3 Total Nitrogen (N), Total Carbon (C), Cd, Cu,

$\mathrm{Pb}, \mathrm{Zn}$ and concentrations in Spelter contaminated

soil.

\begin{tabular}{ccc}
\hline Fraction & Element & Concentration \\
\hline Total $^{\mathrm{a}}$ & $\mathrm{Cd}$ & $---\mathrm{mg} \mathrm{kg}^{-1}---$ \\
& $\mathrm{Cu}$ & 200 \\
& $\mathrm{~Pb}$ & 850 \\
& $\mathrm{Zn}$ & 8600 \\
Total & $\mathrm{C}$ & 2.9 \\
Total & $\mathrm{N}$ & 0.15 \\
\hline
\end{tabular}

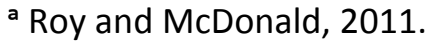




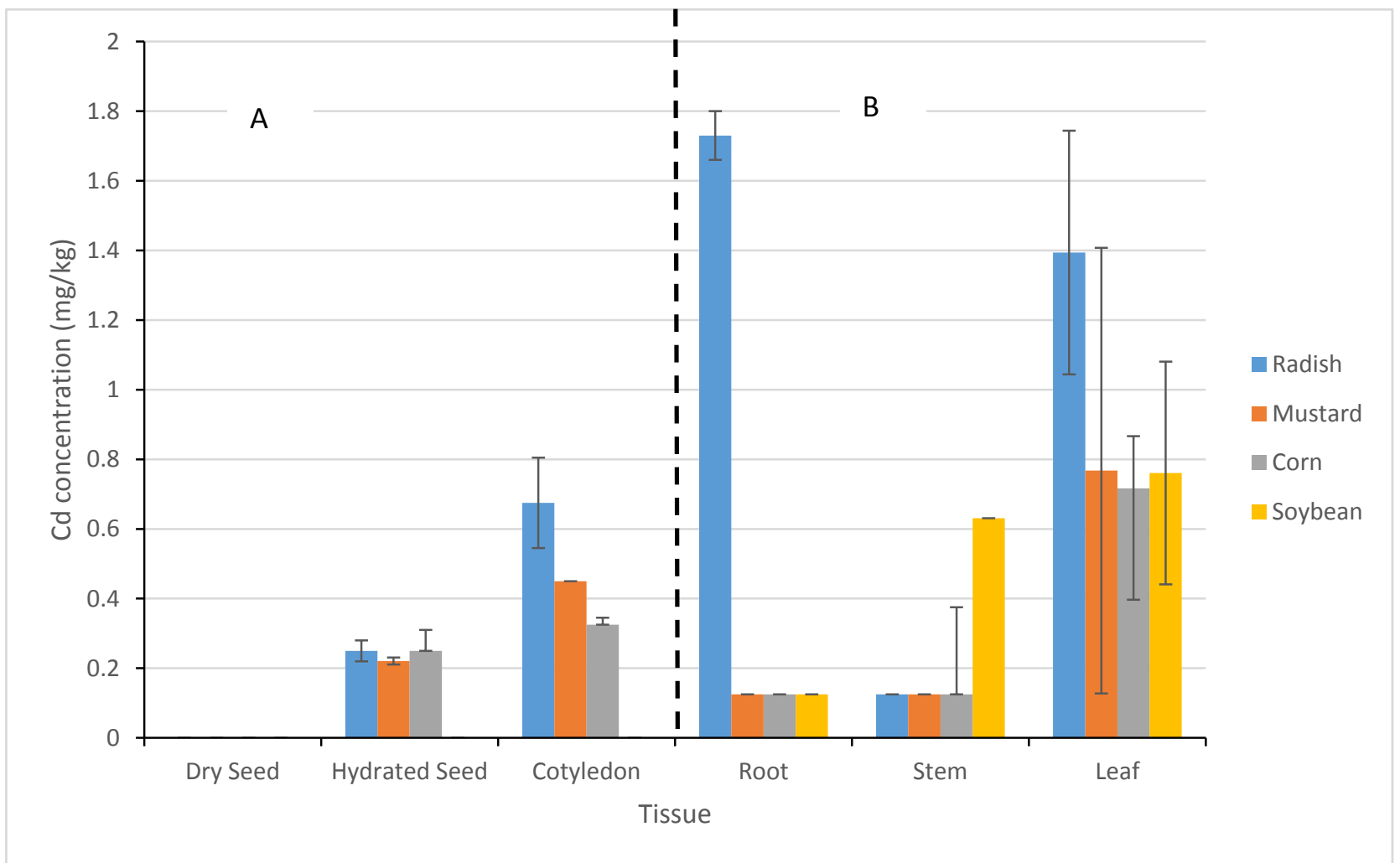

Figure 2-1. Mean Cd concentration in dry seeds, hydrated seeds, cotyledons (A) from the petri dish experiment and roots, stems, and leaves (B) in the whole plant experiment for radish, Indian mustard, corn, and soybean (error bars indicate one standard deviation, $\alpha=0.05$.) 


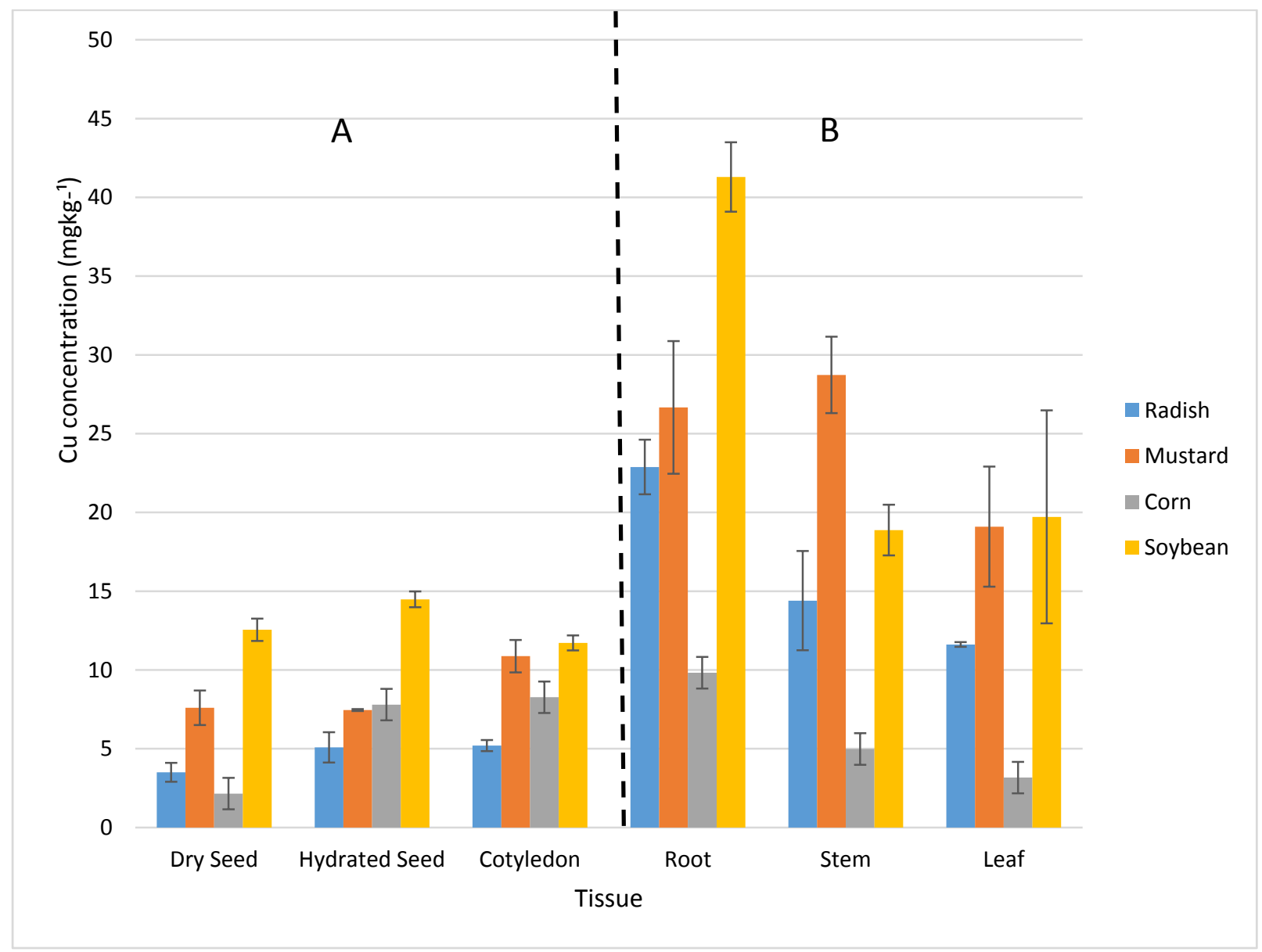

Figure 2-2 Mean Cu concentration in dry seeds, hydrated seeds, cotyledons (A) from the petri dish experiment and roots, stems, and leaves (B) in the whole plant experiment for radish, Indian mustard, corn, and soybean (error bars indicate one standard deviation, $\alpha=0.05$.) 


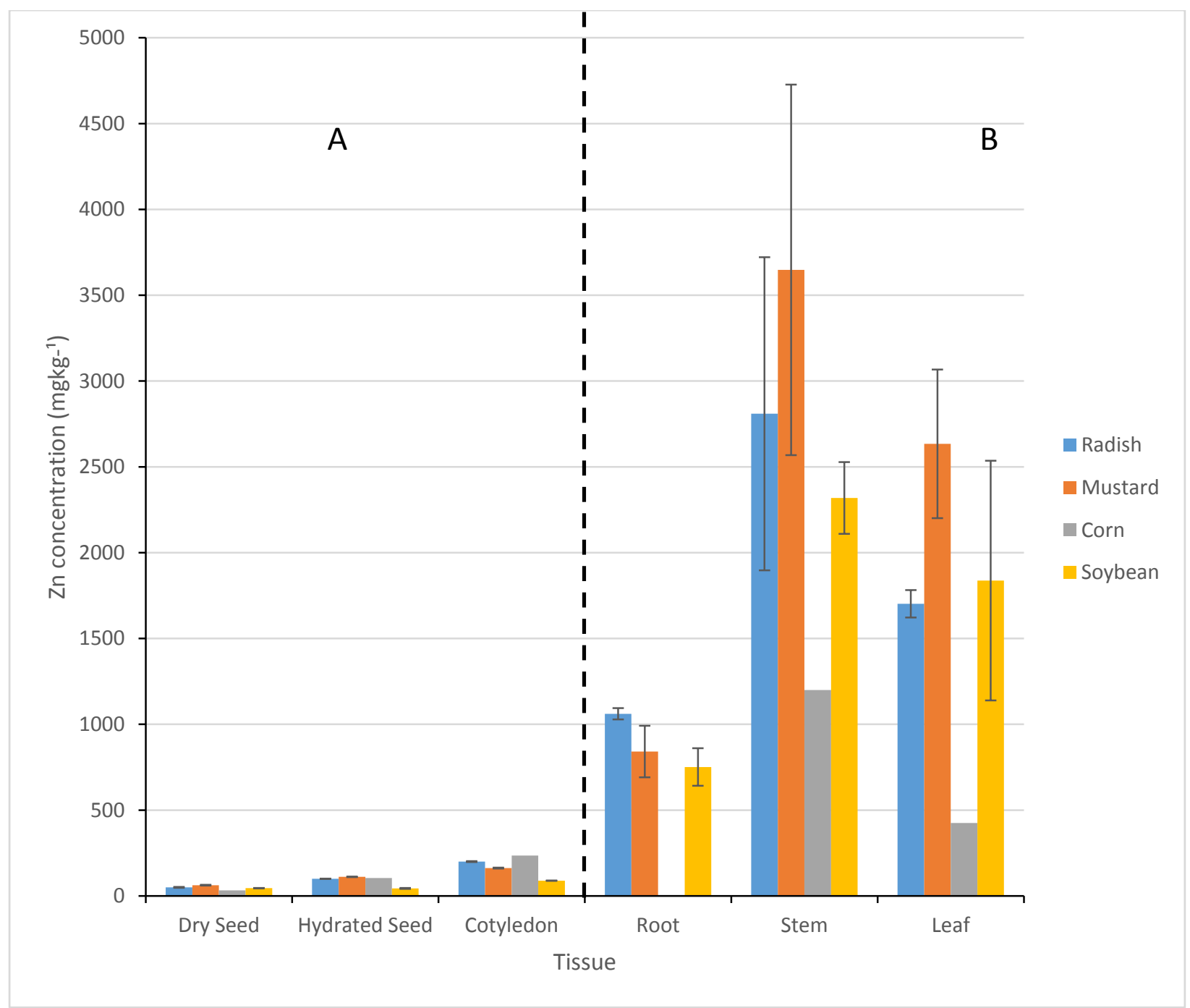

Figure 2-3 Mean Zn concentration in dry seeds, hydrated seeds, cotyledons (A) from the petri dish experiment and roots, stems, and leaves (B) in the whole plant experiment for radish, Indian mustard, corn, and soybean (error bars indicate one standard deviation, $\alpha=0.05$.) 




Figure 2-4 Mean Pb concentration in dry seeds, hydrated seeds, cotyledons $(A)$ from the petri dish experiment and roots, stems, and leaves (B) in the whole plant experiment for radish, Indian mustard, corn, and soybean (error bars indicate one standard deviation, $\alpha=0.05$.) 


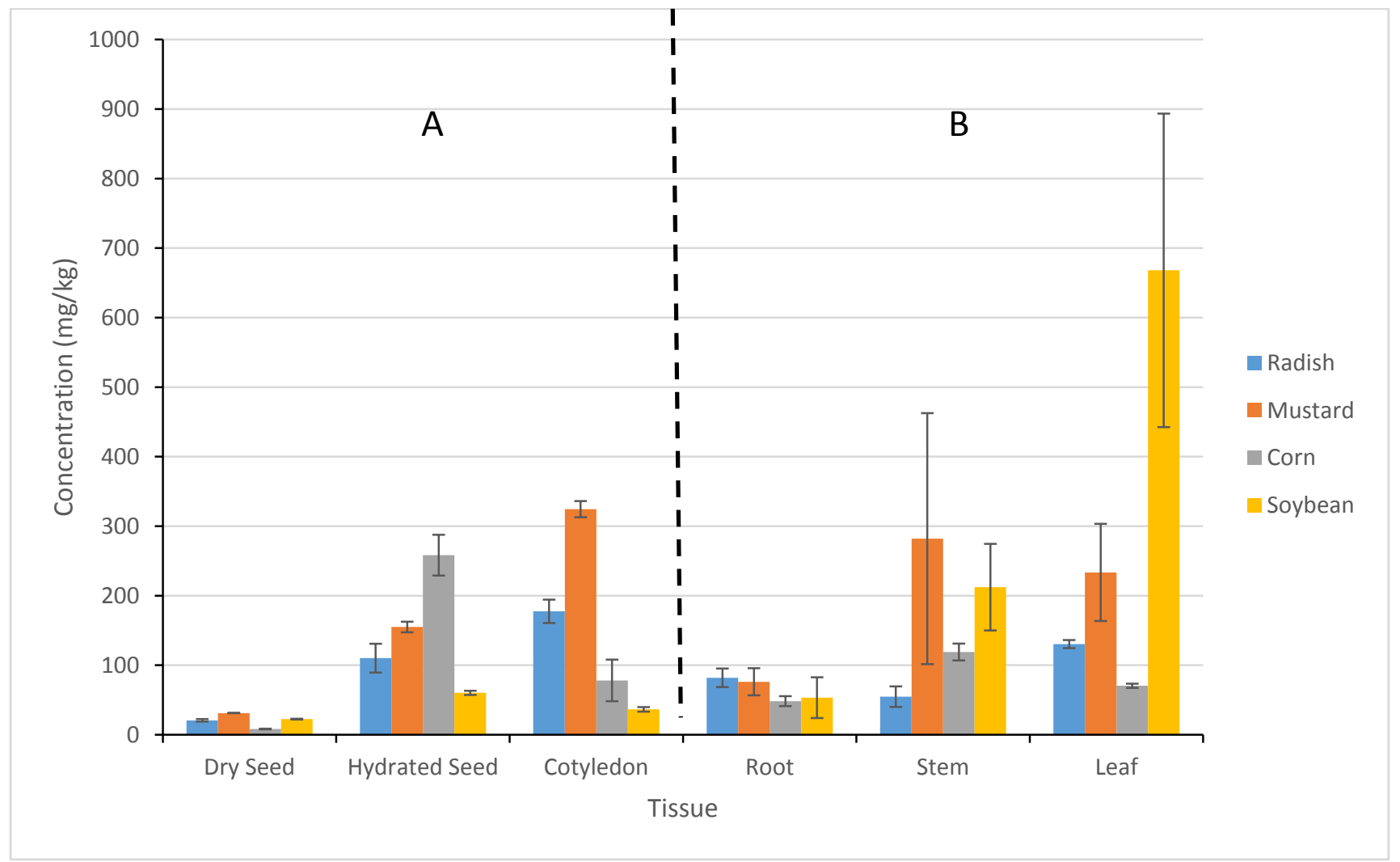

Figure 2-5 Mean Mn concentration in dry seeds, hydrated seeds, cotyledons (A) from the petri dish experiment and roots, stems, and leaves (B) in the whole plant experiment for radish, Indian mustard, corn, and soybean (error bars indicate one standard deviation, $\alpha=0.05$.) 


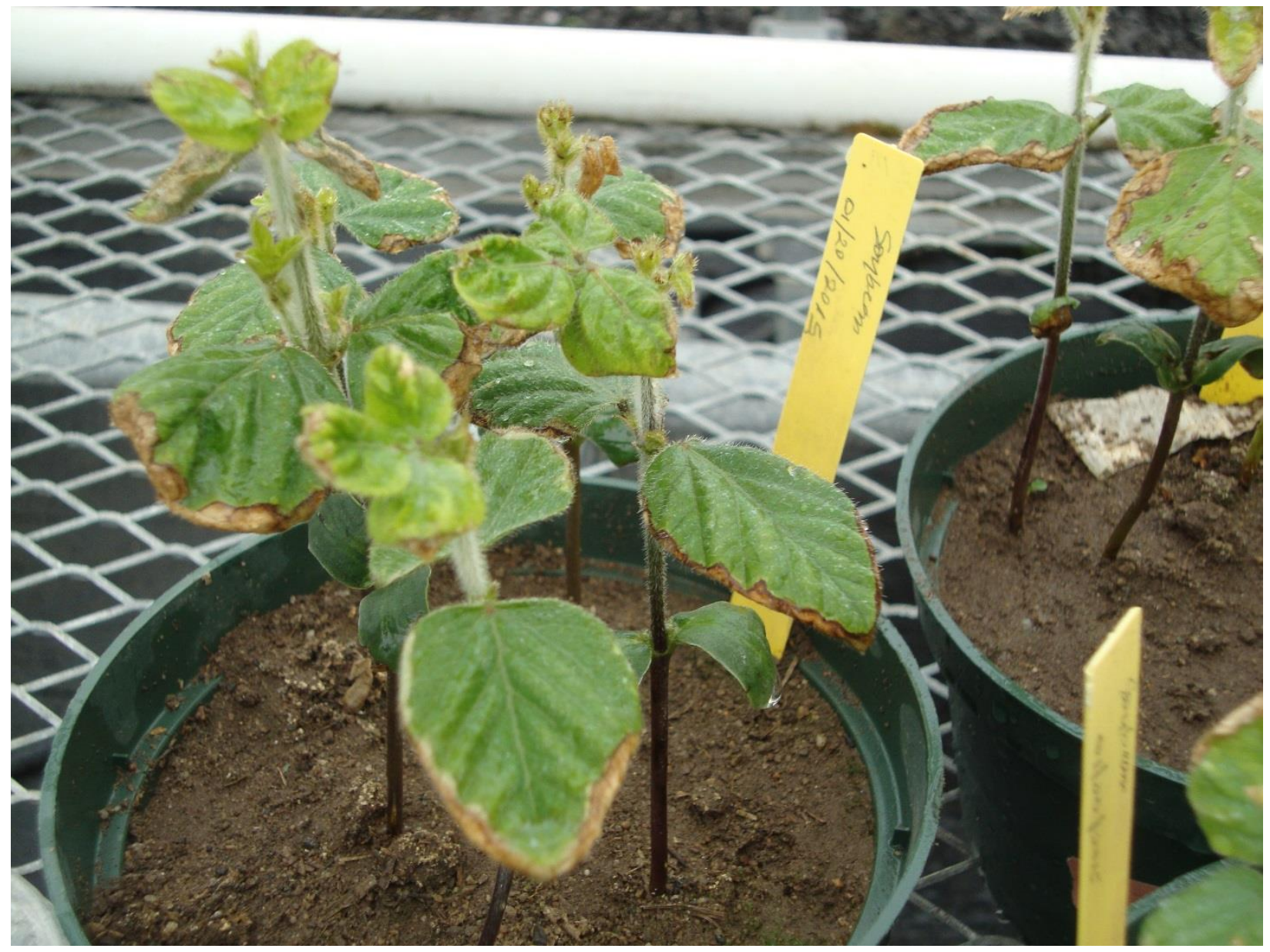

Figure 2-6 Marginal leaf chlorosis in soybean grown on Spelter soil attributed to Mn toxicity. 


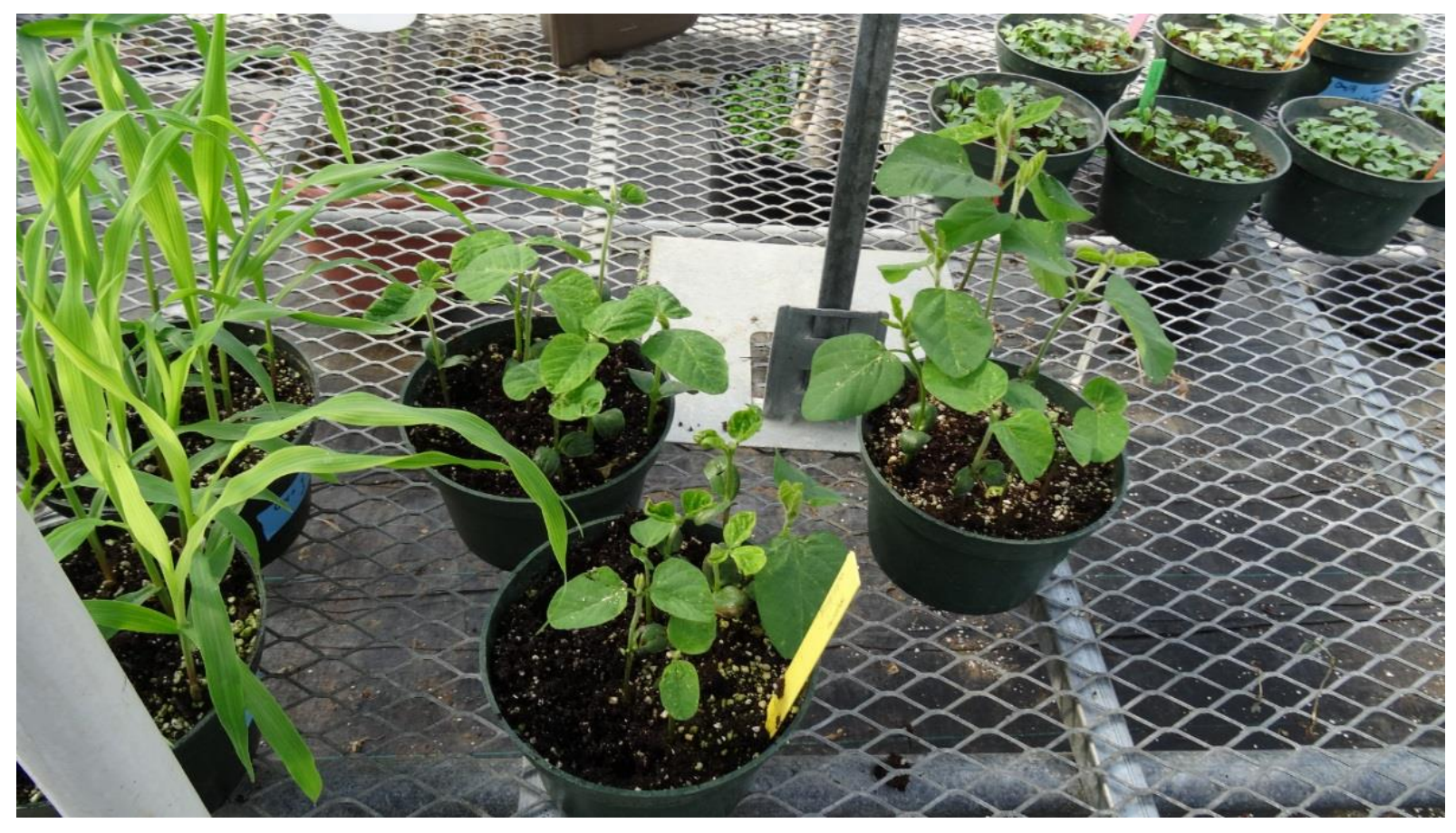

Figure 2-7 Control plants grown on greenhouse media- healthy with no marginal leaf chlorosis. 


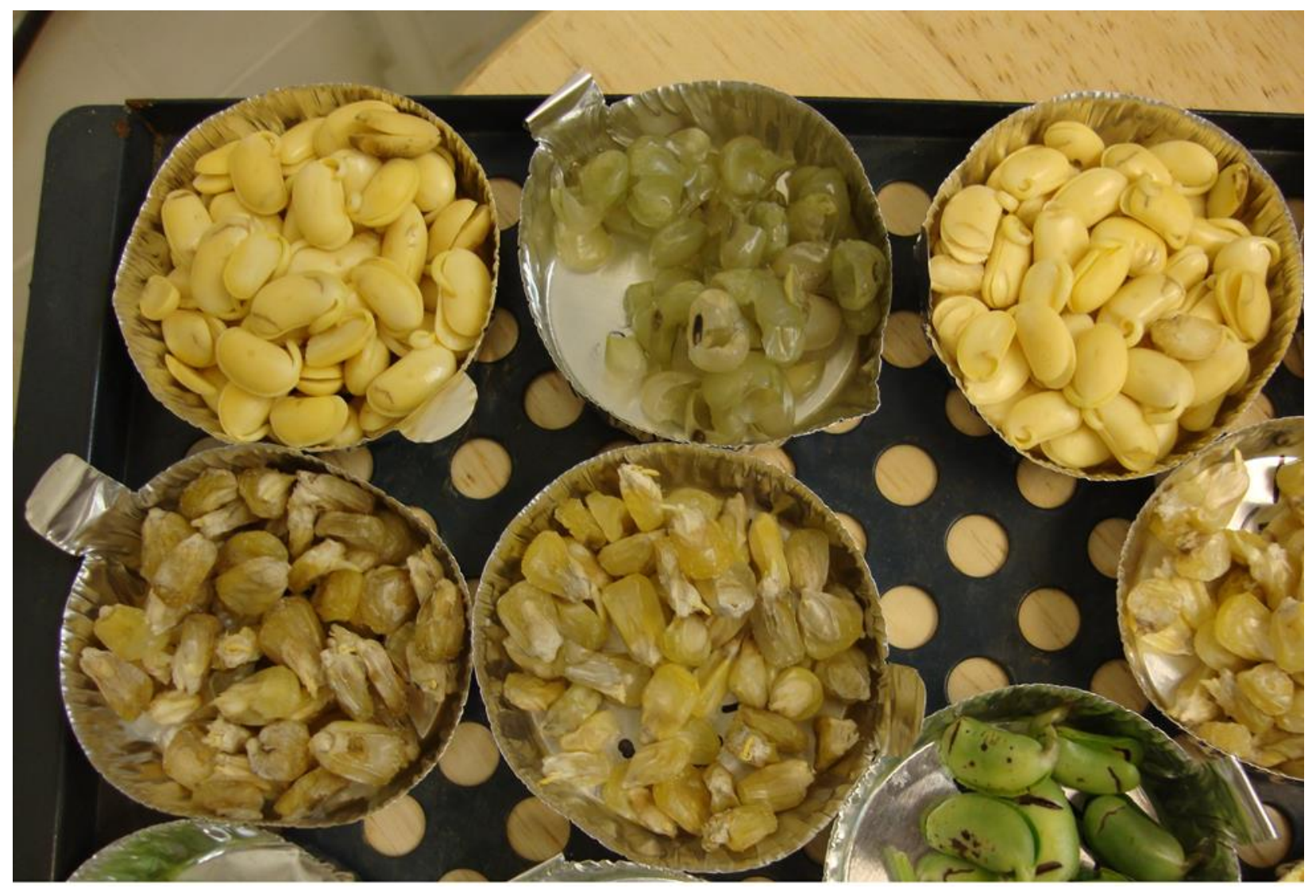

Figure 2-8 Hydrated Soybean cotyledon (after separation drom seed coats), and corn endosperm. 


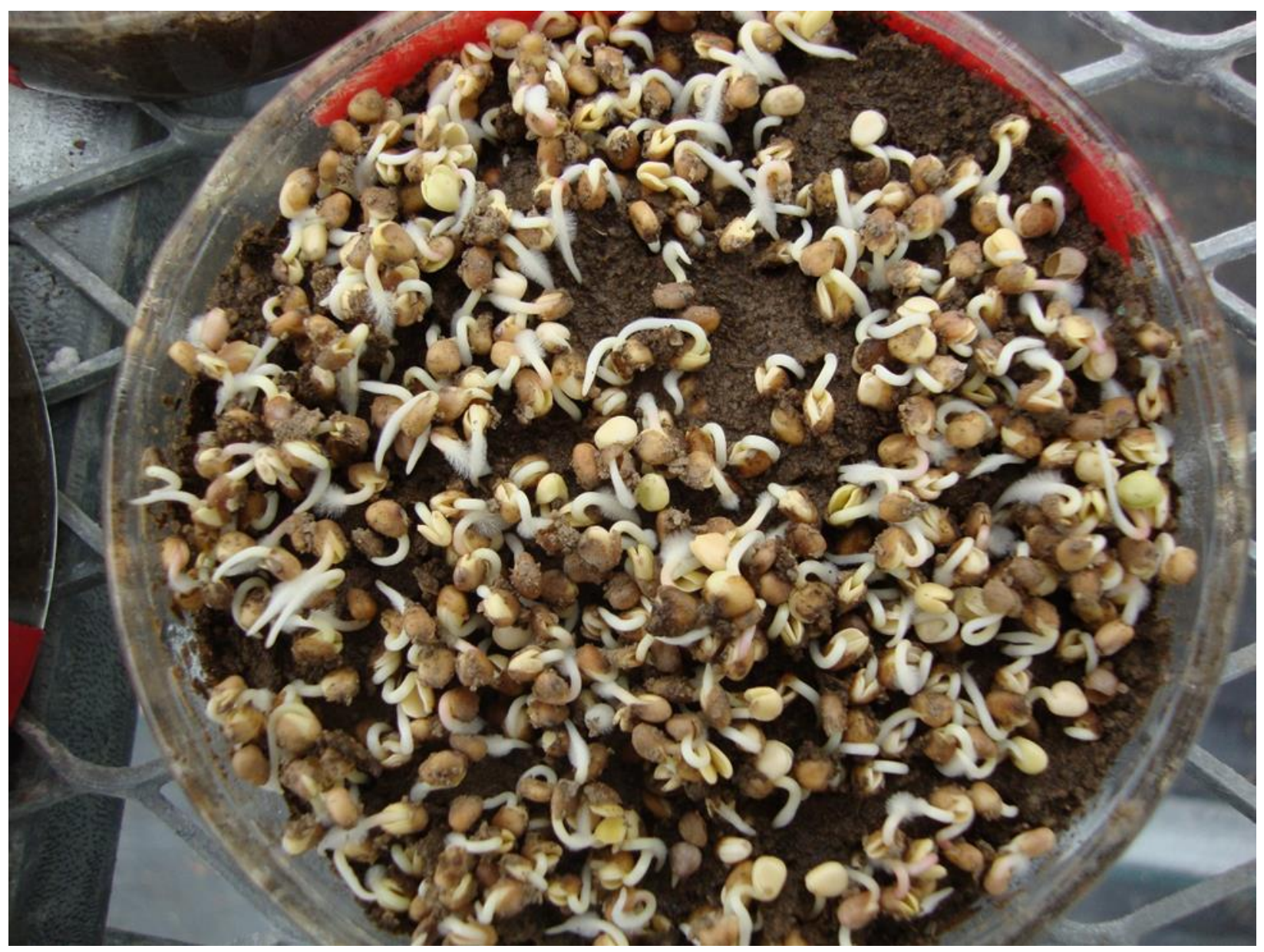

Figure 2-9 Emerged cotyledons of radish seeds after 24 hours. 


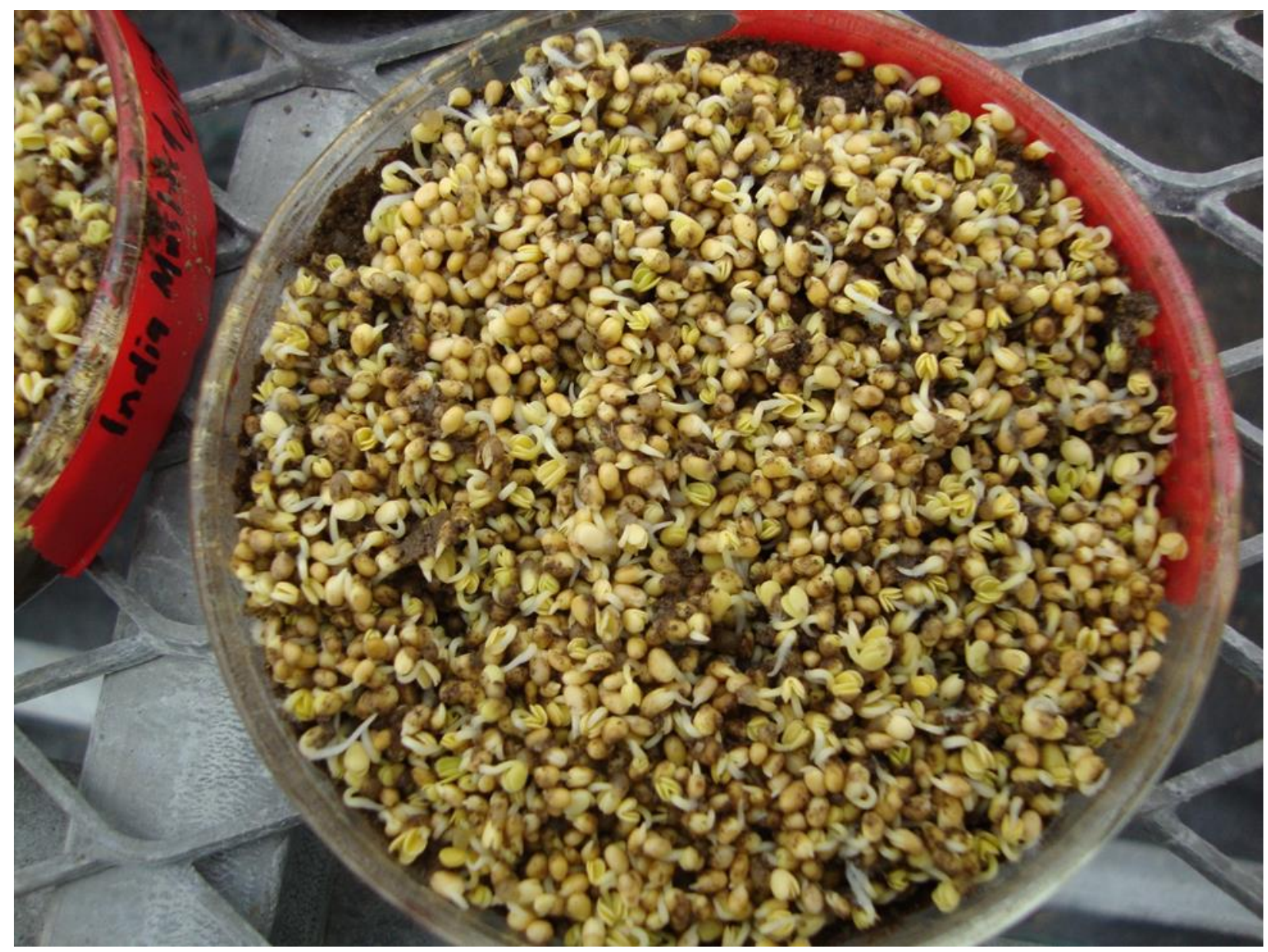

Figure 2-10 Emerged cotyledon of Indian mustard seeds after 24 hours. 


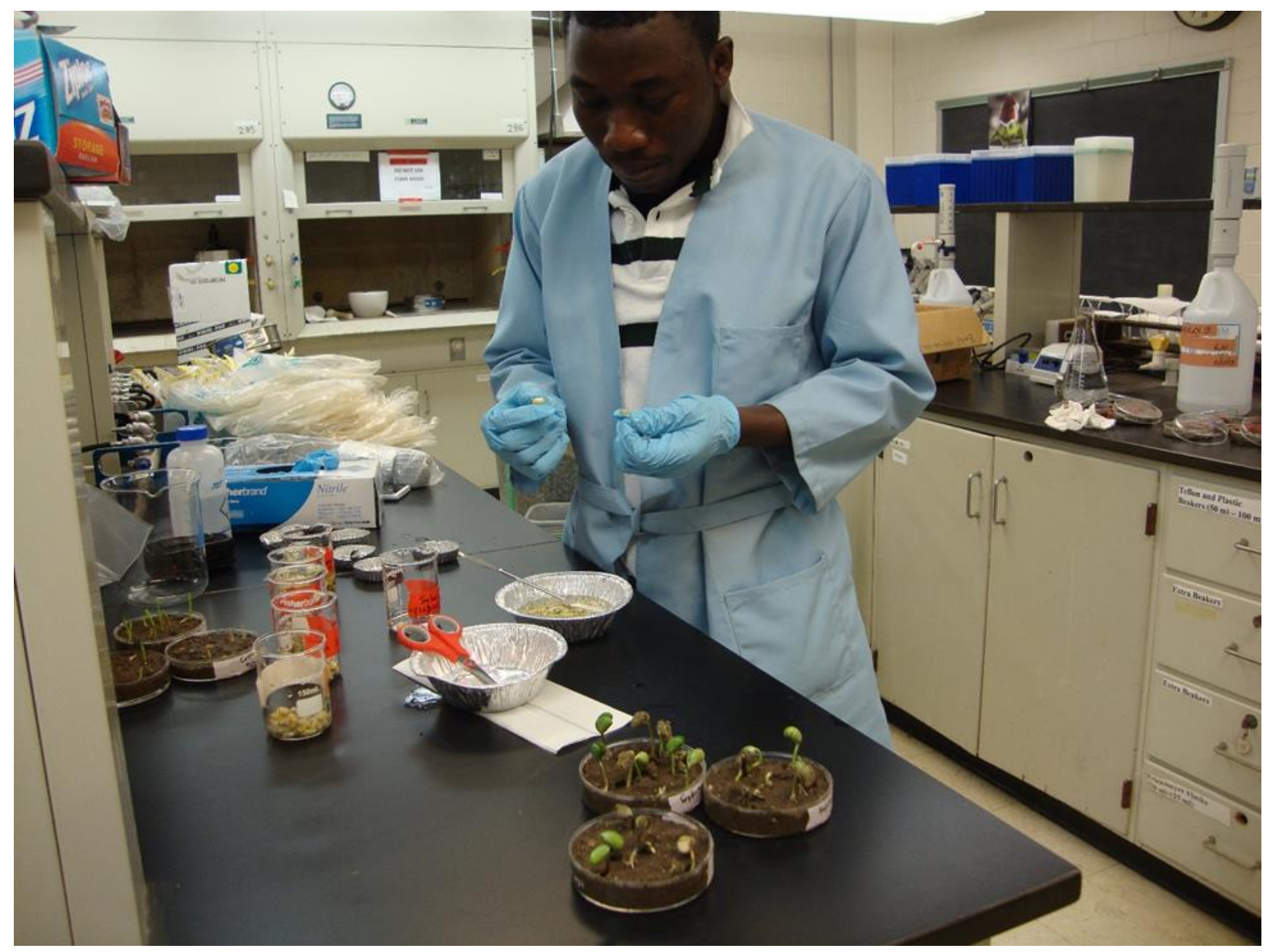

Figure 2-11 Separation of seed coat from the cotyledon, corn endosperm (10 day old), and soybean cotyledon (10 day old). 


\section{Effect of Lead Treatments on Radish Plant Uptake and Potential Interaction with Manganese, Zinc, Lead, Cadmium, and Copper}

\subsection{Introduction}

Approximately 50,000 metal-contaminated sites require remediation in the US alone (Ensley et al., 2000) and nearly $80 \%$ of 217,000 Superfund sites (Priority Sites according to US EPA) contain heavy metals (Ensley et al., 2000). Due to potential toxicity and persistence of heavy metals, the cleanup of contaminated soils is one of the most difficult tasks in environmental science (Wu et al., 2007). Current engineering-based techniques are costly and often have negative impact on the environment including soil. Conventional methods for removal of metal contaminated soils include washing, excavation, and burial of contaminated soils. (Glass et al., 1999a). In contrast, phytoremediation or green technology have been projected to be cheaper and more importantly environmental-friendly as an alternative approach because it is a solar driven, in situ method that minimizes cost and exposure to human (Salt et al., 2000). The cost of phytoremediation in US are $\$ 7$ to $\$ 8$ billion per year of which $35 \%$ involve metals remediation (Glass et al., 1999a, 1999b).

Nearly all metal contaminated soils contain more than one metal (Angelone and Bini, 1992). For example, combinations of $\mathrm{Pb}$ and $\mathrm{Zn}$ are common in urban soils, while $\mathrm{Pb}, \mathrm{Zn}, \mathrm{Cd}$ and $\mathrm{Cu}$ are usually found in the vicinity of metallurgic smelters. The economic values of phytoremediation will be limited if it can only remove one metal from the soil leaving other heavy metals in the contaminated soils behind (Kikuchi et al., 2013). To understand the effect of metal interactions in multi-metal contaminated soils, Kikuchi et al.,2013 carried out two field surveys in Portugal and Poland to determine whether Eucalyptus could remove $\mathrm{Zn}$ and $\mathrm{Pb}$ from an abandoned mine at Sanguinheiro (rich in galena and sphalerite). They reported that although results of the 2-years survey on this site indicated high phytoextraction efficiencies of $\mathrm{Zn}$ but not $\mathrm{Pb}$, also they could not establish clear relationships between leaf chemistry and soil chemistry. It is well known that metal contaminants must come in contact with the root system for metal uptake. It has also been well established that plants and metals interact in the root environment. However, the chemical and biological mechanisms of heavy metal uptake by plant are unknown. The potential for phytoremediation is partly dependent upon the interaction among soil, contaminants, and plants. Taiz and Zeiger (2010) reported that absorption of heavy metals by roots is controlled by the concentration of other elements in the soil solution. Such interactions may be positively or inversely correlated. Uptake of a heavy metal may either be enhanced or suppressed by the 
concentration of other elements in the soil. Heavy metals frequently interact strongly with the soil matrix, and soil conditions can largely influence heavy metal availability.

Spelter, WV (Harrison County) is the site of a former Zn smelting plant. Improper disposal of wastes and by products resulted in a pile of approximately 20 ha, ranging in depth from $0 \mathrm{~m}$ at the margins to $30 \mathrm{~m}$ at the deepest point. Located adjacent to the West Fork River, material from the pile has contaminated residential soils, including a playground, the river, and its sediments with $\mathrm{Zn}, \mathrm{Pb}, \mathrm{Cd}$, $\mathrm{Cu}$ and other metal contaminants of concern (Flowers, 2005; Roy and McDonald, 2013). Unpublished data using the same contaminated soil (McDonald, pers. comm.) suggested a synergistic interaction between $\mathrm{Pb}$ and $\mathrm{Zn}$ uptake. A synergistic effect is when one metal has the ability to enhance the toxicity or uptake of another metal. However, this interaction was speculative because $\mathrm{Pb}$ and $\mathrm{Zn}$ data were not independent. The synergistic effects of metals on plant uptake are poorly understood (Hensley et. al., 2004).

The objective of this study was to determine if there was a synergistic, antagonistic or additive effect for lead and zinc uptake in radish (Raphanus sativus var. Cheriette) when grown in the Spelter soil.

\subsection{Materials and Methods}

Contaminated soil for this study was collected from near Spelter in Harrison County WV. Collected soil samples from this site were brought to WVU greenhouse, air dried, screened through a 2 $\mathrm{mm}$ sieve, and stored in plastic bags.

The treatments were prepared by adding $0 \mathrm{mg} \mathrm{kg}^{-1}$ (control), $300 \mathrm{mg} \mathrm{kg}^{-1}, 600 \mathrm{mg} \mathrm{kg}^{-1}, 900 \mathrm{mg}$ $\mathrm{kg}-1$, and 1, $200 \mathrm{mg} \mathrm{kg}^{-1} \mathrm{~Pb}$ as lead nitrate to soils that contained $850 \mathrm{mg} \mathrm{kg-}^{-1}$ total $\mathrm{Pb}$ and $26 \mathrm{mg} \mathrm{kg}^{-1}$ Mehlich 3 extractable $\mathrm{Pb}$ (Table 2-2). These concentrations chosen were to represent a range of lead contaminations based on USEPA (1996) guidelines. Metal solutions were mixed with soil to ensure homogeneity and placed in plastic pots. Lead nitrate was used because lead chloride forms strong aqueous $\mathrm{Pb}$-complexes while sulfate, carbonate and phosphate are too insoluble. It is well known that metal salts are not equivalent to in situ metal contaminants. Thus, the Pb-metal contaminated soil mixture was allowed to incubate in the dark at room temperature for three weeks to overcome at least some of this problem. Radish seeds were then sown and later thinned to six per pot. At about 12 weeks, radish was harvested, washed thoroughly with DDI water; leaves were separated and oven dried $\left(65^{\circ} \mathrm{C}\right)$ for 2-3 days. Because there was insufficient mass of contaminated soil, there were two replicates per $\mathrm{Pb}$ 
nitrate treatment and a total of 10 pots were used. For each treatment, $\mathrm{Zn}, \mathrm{Mn}, \mathrm{Cd}, \mathrm{Cu}$, and $\mathrm{Pb}$ concentrations were determined on dried tissues weight basis as described above. Therefore, only means are reported. The study was conducted in plastic pots in the greenhouse and the pots were watered daily to approximate field capacity (never saturated nor allow to drain). Linear regression and ANOVA were used to analyze data for synergistic and /or antagonistic interactions among these metals. The NSB Tomato Leaf standard was used for QA/QC as described above.

\subsection{Results and Discussion}

Our results showed that $\mathrm{Pb}$ had a synergistic effect on $\mathrm{Zn}$ uptake at low added lead concentrations and an antagonistic effect at higher added lead concentrations (Figure 3.1A). The transition point was at about $300 \mathrm{mg} \mathrm{kg}^{-1}$ added $\mathrm{Pb}$. There was a synergistic effect of added lead on $\mathrm{Mn}$ uptake (Figure 3-1B) and for Cd and Cu uptake (Figure 3-1C).

Although this experiment lacks the statistical power to make definitive conclusions the trends are sufficiently strong to warrant further investigation. If confirmed with more controlled experiments and with experiments that test the opposite effect ( $\mathrm{Zn}$ additions to $\mathrm{Pb}$ contaminated soils) then these results suggest that current approaches to characterize the potential for metal uptake from multi-metal contaminated soils are inadequate. Specifically, that spiking contaminated soils with and measuring uptake of a single metal may lead to inaccurate results, and more importantly, that it is not possible to predict metal uptake without properly accounting for all metal concentrations in the system. 


\section{References}

Angelone, M., Bini, C. 1992. Trace element concentrations in soils and plants of Western Europe. In: Adriano, D.C. (ed.), Biogeochemistry of Trace Metals. pp. 19-60.

Bahemuka, T.E., Mubofu, E.B. 1999. Heavy metals in edible green vegetables grown along the sites of the Sinza and Msimbazi rivers in Dar es Salaam, Tanzania. Food Chemistry 66: 63-66.

Ensley, B.D. 2000. Rationale for use of phytoremediation. In: Raskin, I. and Ensley, B.D. (eds.), Phytoremediation of toxic metals- using plants to clean up the environment. pp. 1-12. New York: Wiley.

EPA - Environmental Protection Agency. 1998. A citizen's guide to phytoremediation. (\#542-F-98-011). Washington DC: EPA Publications.

Hensley, Kenneth, et al. 2004. Conferences at the Oklahoma Medical Research Foundation. The Journal of Neuroscience.

Kikuchi, T., Tanaka, S. 2012. Biological removal and recovery of toxic heavy metals in water environment. Critical Review of Environmental Science Technology. 42 (10): 1007-1057.

Glass, D.J. 1999a. Economic potential of phytoremediation. In: Raskin, I. and Ensley, B.D. (eds.), Phytoremediation of toxic metals - using plants to clean up the environment. (pp. 15-33). New York: Wiley.

Glass, D.J. 1999b. U.S. and International Markets for Phytoremediation. 1999-2000. D. Glass Associate Inc., Needham. MA.

Horne, A.J. 2000. Phytoremediation by constructed wetlands. In: Phytoremediation of Contaminated Soil and Water. pp. 13-40. Terry, N. and Bañuelos, G., Eds., Lewis, Boca Raton, Florida.

Marmiroli N., Marmiroli M., Maestri E., 2006. Phytoremediation and phytotechnologies: a review for the present and the future. In: Soil and water pollution monitoring, protection and remediation. Twardowska I. et al. (eds), Springer. pp. 403-416.

Peralta-Videa, J.R., Gardea-Torresdey, J.L., Gomez, E., Tiemann, K.J., Parsons, J.G., De la Rosa, G., and Carrillo, G. 2002. Potential of alfalfa plants to phytoremediate individually contaminated montmorillonite-soils with cadmium, chromium, copper, nickel, and zinc. Bull. Environ. Contam. Tox. 69, 74-81. 
Salt, D.E., Smith, R.D. and Raskin, I. 1998. Phytoremediation. Annual Review of Plant Physiology and Plant Molecular Biology 49: 643-668.

Slater, A. 2000. Some possible future limitations on the commercial application of metal phytoremediation. In: abstract book of Phytoremediation - state of the art in Europe. pp. 2-3. Hersonissos, 6-8 April: 1st scientific workshop of COST action \#837.

Slaveykova, V.I., Wilkinson, K.J. 2002. Physicochemical aspects of lead bioaccumulation by Chlorella vulgaris. Environmental Science and Technology 36: 969-975.

Wu L.H., Luo Y., Song J. 2007. Manipulating soil metal availability using EDTA and low-molecular-weight organic acids. In: Willey N (ed) Methods in biotechnology: phytoremediation. Methods and reviews. Humana, Mahwah, NJ.

Yang, X., Long, X.X., Ni, W.Z., \& Fu, C.X. 2002. Sedum A. H: A new Zn hyperaccumulating plant first found in China. Chin. Science. Bulletin. 47: 1634-1637. 


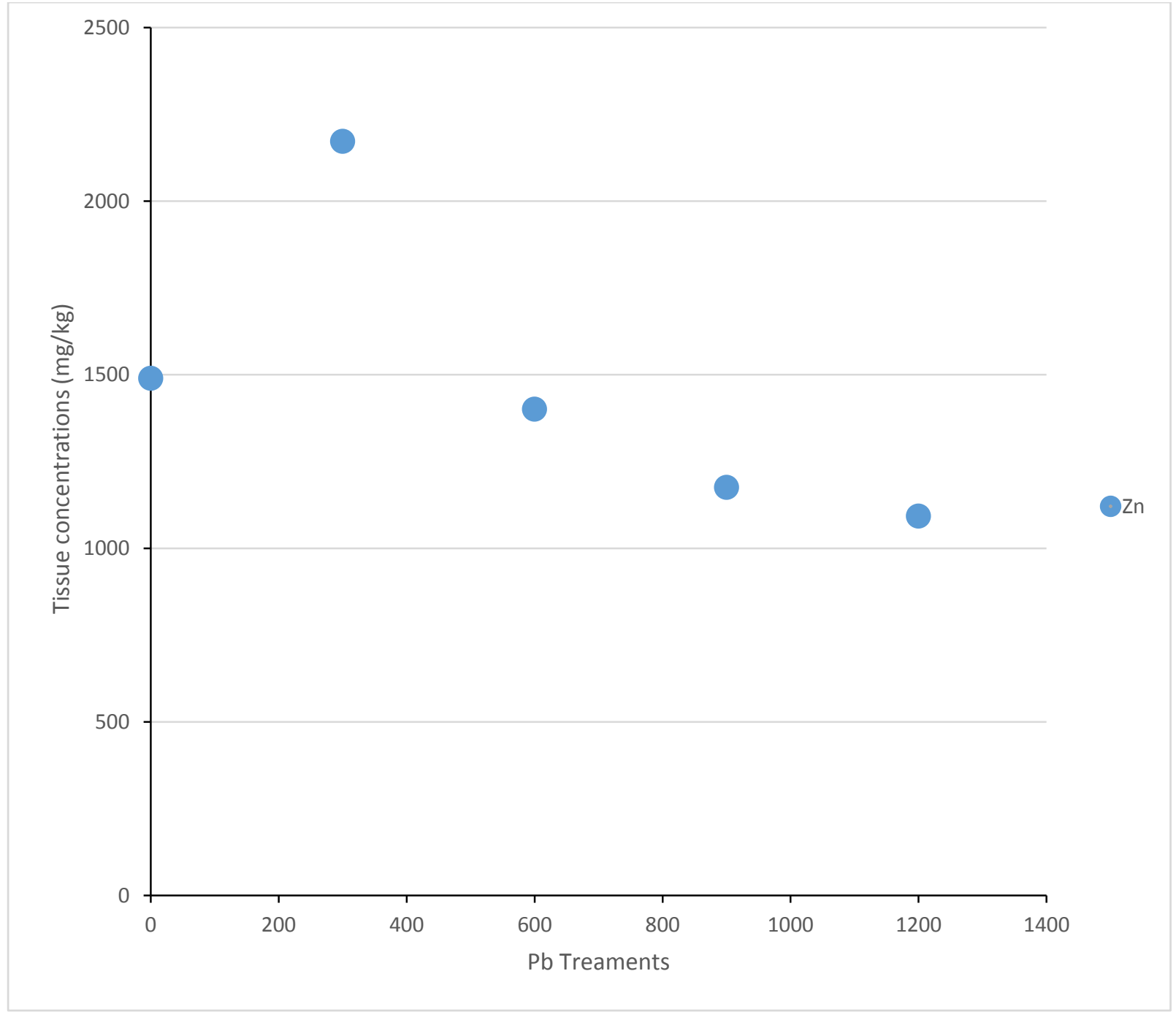

Figure 3-1 Effect of added lead nitrate on radish leaf zinc concentrations. 


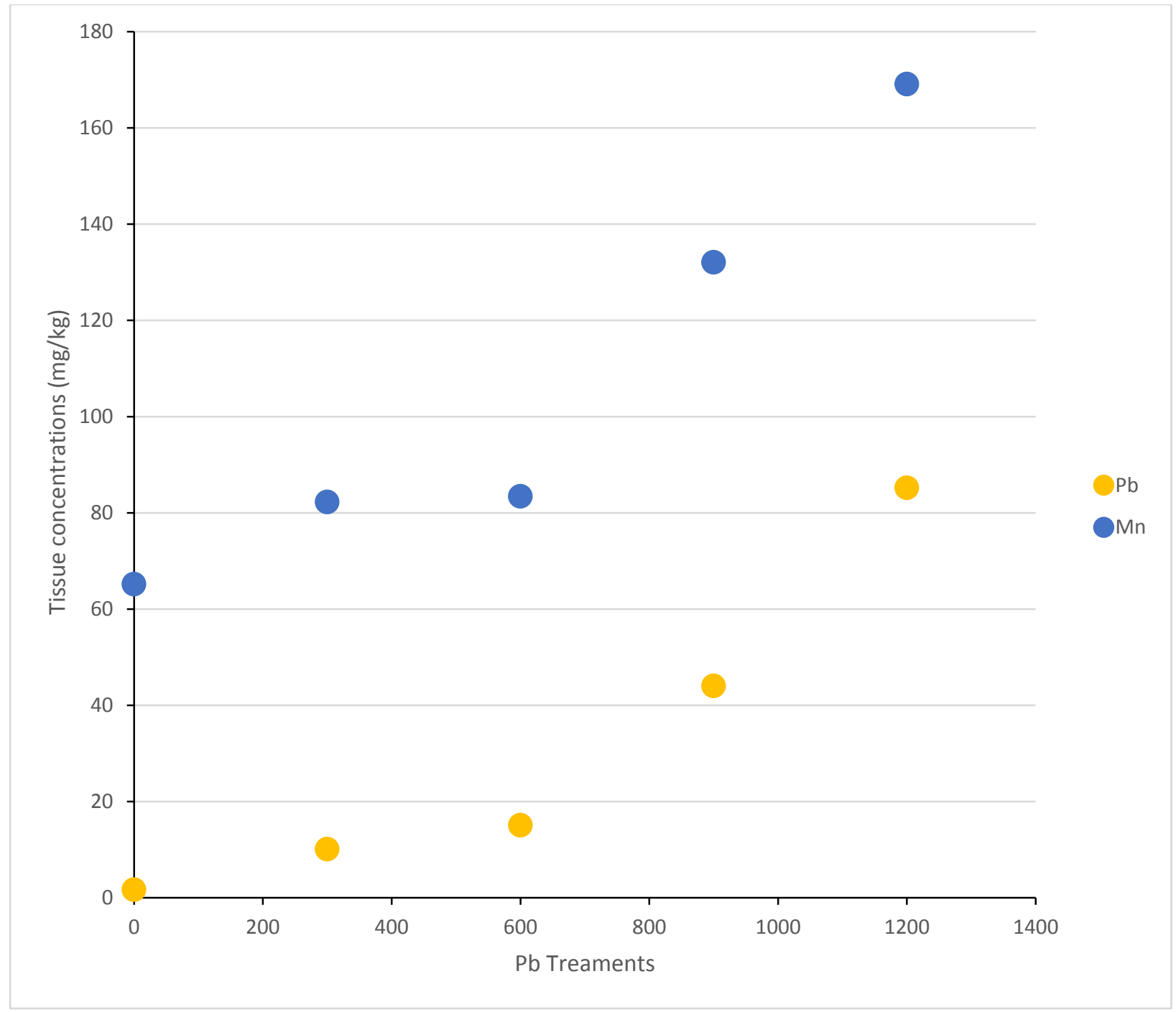

Figure 3-2 Effect of added lead nitrate on radish leaf $\mathrm{Pb}$ and $\mathrm{Mn}$ concentrations. 


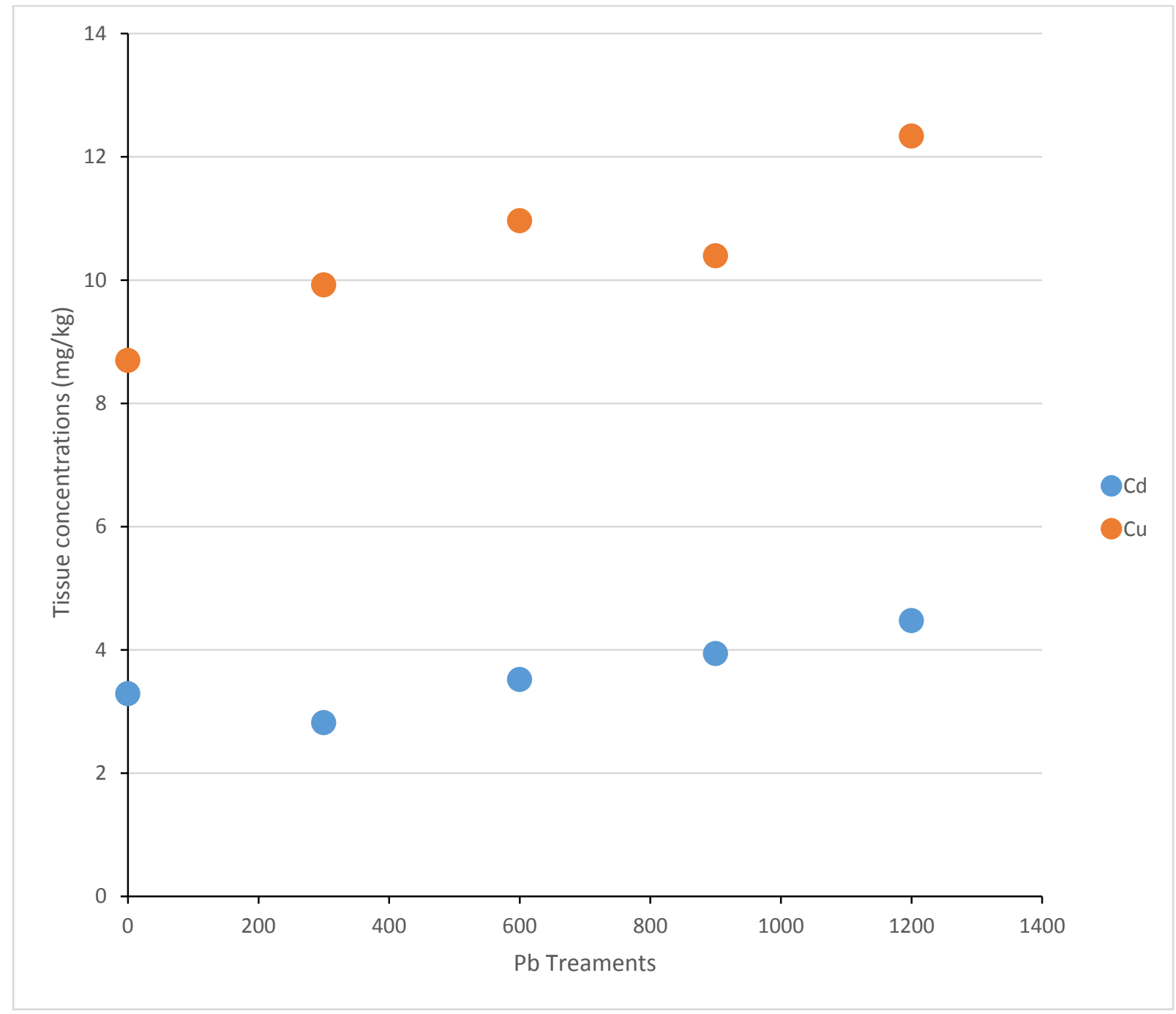

Figure 3-3 Effect of added lead nitrate on radish leaf $\mathrm{Cd}$ and $\mathrm{Cu}$ concentrations. 


\section{Summary and Conclusion}

\subsection{Summary}

4.1.1 Uptake of heavy metals by four species of plants

It was noted that metal uptake was both species and metal specific. All the four species had varying degree of tolerance to heavy metals. Indian mustard exhibited most growth retardation and phytotoxicity effect and was perhaps the most sensitive species among those species studied. Indian mustard showed some visible symptoms- poor and stunted growth rate, poor root development, low biomass production as well as, chlorosis and necrosis. However, it had highest capability to uptake metal in its tissue. Also observed in this study was $\mathrm{Mn}$ toxicity in soybean specifically marginal leaf chlorosis which is an important symptoms of $\mathrm{Mn}$ toxicity was reported. Another notable observation in this study was, unlike control greenhouse mix, radish plant failed to develop bulbs. This was attributed to toxicity effects of the heavy metals on radish growth and development. Cadmium concentrations were lower or moderate in uptake by the four species. Zinc and $\mathrm{Mn}$ were present in abundance for all the four species, although Mn soil uptake was variable because of slight pH differences in soil. Copper concentrations were moderate in the species studied. This is in agreement with results from Interwongse et al., 2007. The four species could be grouped as follow (Anton and Mathe-Gaspar, 2005): radish- accumulator and tolerant species, Indian mustard- accumulator and sensitive species, soybean-accumulator and moderately sensitive species, corn- a fair potential accumulator and tolerant species. The orders of metal accumulations was as follow: for $\mathrm{Cd}$ and $\mathrm{Cu}$ root>stem $>$ leaf $>$ cotyledon $>$ hydrated seed $>$ dry seed, except for $\mathrm{Cd}$ contents in radish root and Cu content in Indian mustard stem; for $\mathrm{Zn}$ stem>leaf>root> cotyledon>hydrated seed>dry seed, except for soybean leaf where root> leaf; for $\mathrm{Pb}$ root>stem>leaf $>$ cotyledon>hydrated seed>dry seed, except for Indian mustard and radish (both belongs to the same family) where stem>root. Note that no trend was observed for Mn. 


\section{Appendix}

Table 2-4 Mean Cd concentration in radish, Indian mustard, corn, and soybean

\begin{tabular}{|c|c|c|c|c|c|c|}
\hline $\mathrm{Cd}$ & Dry Seed & Hydrated Seed & Cotyledon & Root & Stem & Leaf \\
\hline \multicolumn{7}{|c|}{ 1 } \\
\hline Radish & nd & $0.25^{\mathrm{a}}$ & $0.68^{\mathrm{a}}$ & $1.73^{\mathrm{a}}$ & $0.13^{\mathrm{a}}$ & $1.39^{\mathrm{a}}$ \\
\hline Indian & nd & $0.22^{\mathrm{a}}$ & $0.45^{\mathrm{a}}$ & $0.13^{\mathrm{b}}$ & $0.13^{a}$ & $0.77^{\mathrm{a}}$ \\
\hline Corn & nd & $0.25^{\mathrm{a}}$ & $0.33^{a}$ & $0.13^{\mathrm{b}}$ & $0.13^{\mathrm{a}}$ & $0.72^{\mathrm{a}}$ \\
\hline Soybean & nd & nd & nd & $0.13^{b}$ & $0.63^{a}$ & $0.76^{a}$ \\
\hline
\end{tabular}

Different letters indicate significant statistical differences for the main effect of species for a given metal at $\alpha=0.05$

*nd -none detected 
Table 2-5 Mean Cu concentration in radish, Indian mustard, corn, and soybean

\begin{tabular}{|c|c|c|c|c|c|c|}
\hline $\mathrm{Cu}$ & Dry Seed & Hydrated Seed & Cotyledon & Root & Stem & Leaf \\
\hline & 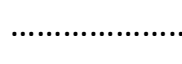 & $\ldots \ldots \ldots \ldots \ldots$ & $\mathrm{mg} / \mathrm{kg} . . . . . . . . . .$. & .................... & …................ & $\ldots \ldots \ldots . . . . .$. \\
\hline Radish & $3.08^{a}$ & $5.08^{c}$ & $5.20^{c}$ & $22.88^{a}$ & $14.40^{b c}$ & $11.62^{\mathrm{a}}$ \\
\hline Indian & $6.83^{b}$ & $7.46^{\mathrm{bc}}$ & $10.88^{\mathrm{ab}}$ & $26.67^{a}$ & $28.73^{a}$ & $19.10^{\mathrm{a}}$ \\
\hline Corn & $2.20^{c}$ & $7.80^{b}$ & $8.27^{b c}$ & $9.82^{a}$ & $4.98^{c}$ & $3.17^{\mathrm{a}}$ \\
\hline Soybean & $13.05^{c}$ & $14.48^{\mathrm{a}}$ & $11.72^{\mathrm{a}}$ & $41.29^{a}$ & $18.88^{b}$ & $19.72^{\mathrm{a}}$ \\
\hline
\end{tabular}


Table 2-6 Mean Zn concentration in radish, Indian mustard, corn, and soybean

\begin{tabular}{|c|c|c|c|c|c|c|}
\hline $\mathrm{Zn}$ & Dry Seed & Hydrated Seed & Cotyledon & Root & Stem & Leaf \\
\hline \multicolumn{7}{|c|}{-1.1. } \\
\hline Radish & $52.60^{\mathrm{ab}}$ & $100.03^{a}$ & $200.03^{\mathrm{a}}$ & $1061.26^{a}$ & $2809.24^{a}$ & $1702.09^{a b}$ \\
\hline Indian & $60.01^{\mathrm{a}}$ & $111.28^{\mathrm{a}}$ & $162.4^{\mathrm{a}}$ & $841.45^{\mathrm{a}}$ & $3647.45^{a}$ & $2634.35^{\mathrm{a}}$ \\
\hline Corn & $32.88^{b}$ & $104.28^{\mathrm{a}}$ & $235.28^{\mathrm{a}}$ & $871.37^{\mathrm{a}}$ & $1199.55^{a}$ & $424.55^{b}$ \\
\hline Soybean & $45.95^{c}$ & $43.82^{b}$ & $88.9^{b}$ & $750.98^{a}$ & $2318.43^{a}$ & $1837.48^{a b}$ \\
\hline
\end{tabular}


Table 2-7 Mean Pb concentration in radish, Indian mustard, corn, and soybean

\begin{tabular}{|c|c|c|c|c|c|c|}
\hline $\mathrm{Pb}$ & Dry Seed & Hydrated Seed & Cotyledon & Root & Stem & Leaf \\
\hline Radish & nd & $0.50^{\mathrm{a}}$ & $0.78^{b}$ & $7.01^{\mathrm{a}}$ & $22.39^{a b}$ & $2.977^{b}$ \\
\hline Indian & nd & $1.88^{\mathrm{a}}$ & $7.98^{a}$ & $24.67^{a}$ & $48.00^{\mathrm{a}}$ & $21.95^{\mathrm{a}}$ \\
\hline Corn & nd & $0.43^{a}$ & $1.77^{b}$ & $6.15^{\mathrm{a}}$ & $3.19^{b}$ & $1.22^{\mathrm{b}}$ \\
\hline Soybean & nd & $0.22^{\mathrm{a}}$ & $0.33^{b}$ & $30.82^{a}$ & $5.48^{\mathrm{b}}$ & $6.28^{\mathrm{ab}}$ \\
\hline
\end{tabular}


Table 2-8 Mean Mn concentration in radish, Indian mustard, corn, and soybean

\begin{tabular}{|c|c|c|c|c|c|c|}
\hline $\mathrm{Mn}$ & Dry Seed & Hydrated Seed & Cotyledon & Root & Stem & Leaf \\
\hline Radish & $22.00^{b}$ & $110.17^{b c}$ & $177.53^{b}$ & $81.90^{\mathrm{a}}$ & $54.72^{\mathrm{a}}$ & $130.48^{b}$ \\
\hline Indian & $31.15^{\mathrm{a}}$ & $155.03^{b}$ & $324.53^{a}$ & $76.19^{a}$ & $282.06^{a}$ & $233.48^{\mathrm{ab}}$ \\
\hline Corn & $8.65^{c}$ & $258.32^{\mathrm{a}}$ & $78.14^{\mathrm{bc}}$ & $48.29^{a}$ & $118.94^{a}$ & $70.40^{b}$ \\
\hline Soybean & $23.10^{b}$ & $60.22^{c}$ & $36.50^{c}$ & $53.24^{a}$ & $212.21^{a}$ & $668.01^{a}$ \\
\hline
\end{tabular}

Different letters indicate significant statistical differences for the main effect of species for a given metal at $\alpha=0.05$ 
Table 2-9 Interaction of $\mathrm{Pb}$ treatments on mean uptake $\mathrm{Cd}, \mathrm{Cu}, \mathrm{Zn}, \mathrm{Pb}$, and $\mathrm{Mn}$ in Radish leaf.

\begin{tabular}{llllll}
\hline Pb Treatments. $\mathrm{Cd}$ & $\mathrm{Cu}$ & $\mathrm{Zn}$ & $\mathrm{Pb}$ & $\mathrm{Mn}$. \\
\cline { 1 - 1 } & 3.287820 & 8.695905 & 1489.259 & 1.648142 & 65.16365 \\
$\mathbf{y}$ & 2.816834 & 9.922067 & 2171.738 & 10.07973 & 82.23938 \\
600 & 3.517567 & 10.96368 & 1400.564 & 15.06099 & 83.42045 \\
900 & 3.938278 & 10.39476 & 1175.513 & 44.02840 & 132.0730 \\
1200 & 4.473898 & 12.33543 & 1092.395 & 85.18920 & 169.1071 \\
\hline
\end{tabular}




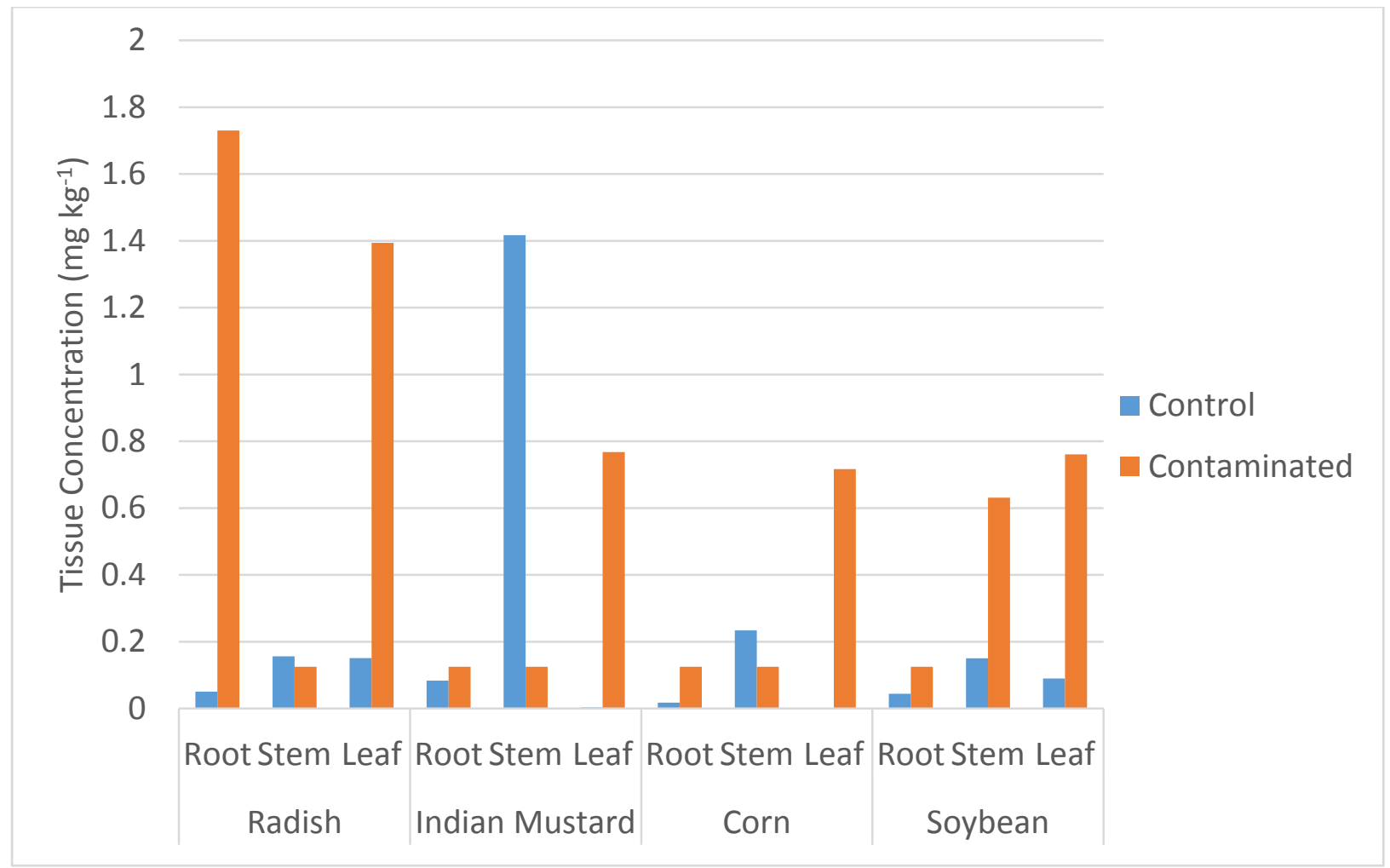

Figure 2-12 Mean Cd concentration in roots, stems and leaves at eight weeks when grown in the greenhouse mix control and the Spelter soil. 


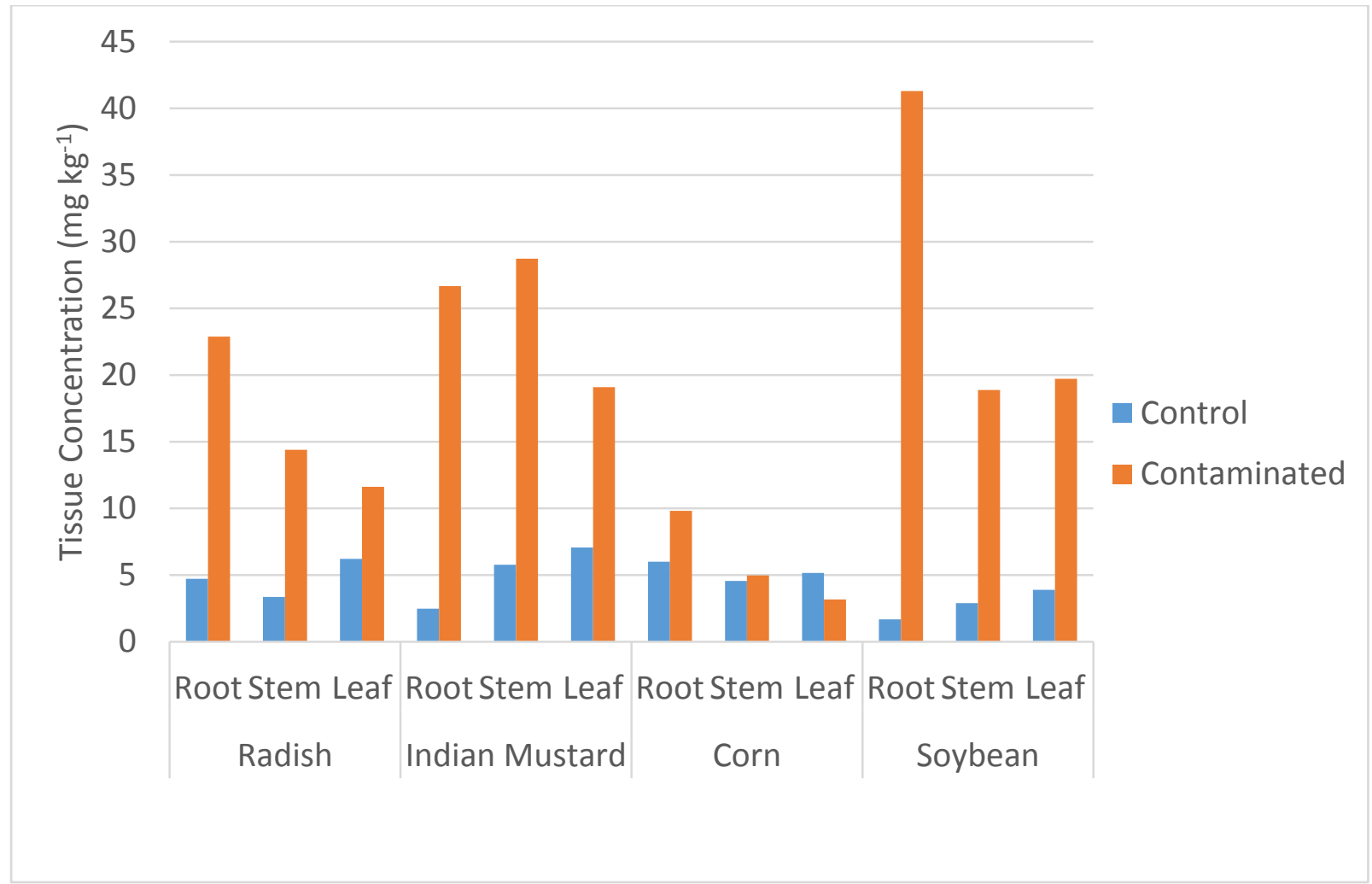

Figure 2-13 Mean Cu concentration in contaminated soil compared with uncontaminated at 8 week. 


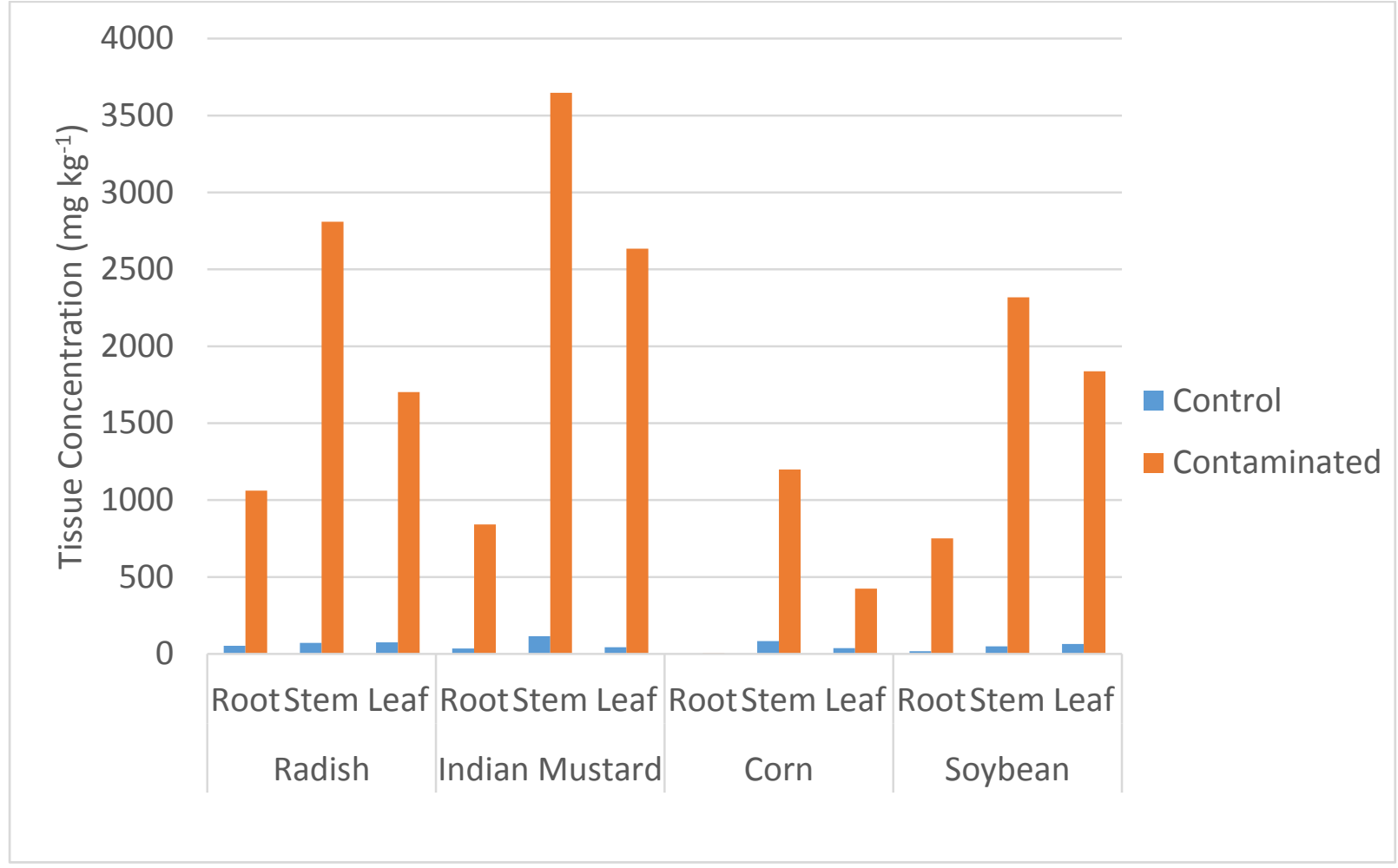

Figure 2-14 Mean Zn concentration in contaminated soil compared with uncontaminated at 8 week. 


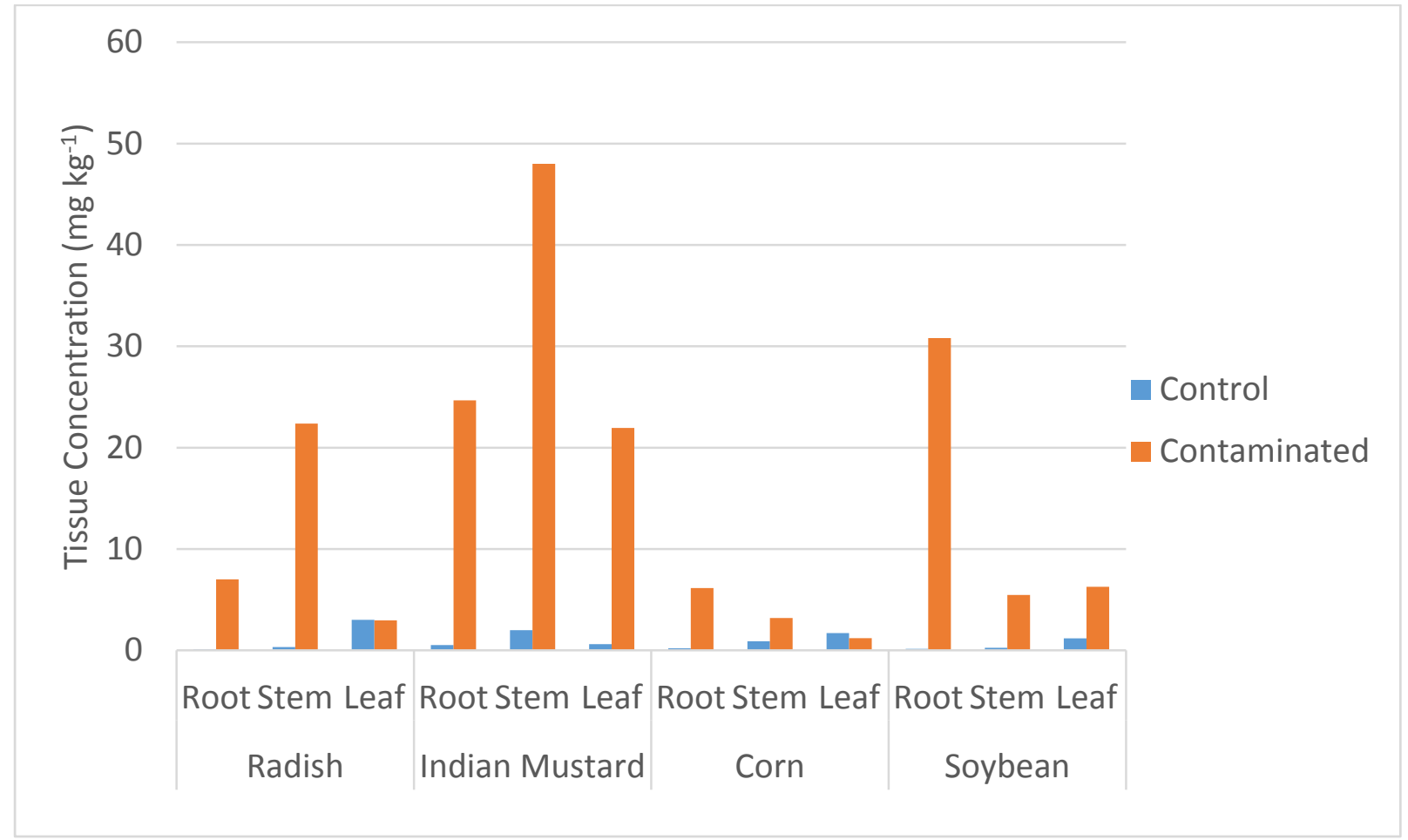

Figure 2-15 Mean Pb concentration in contaminated soil compared with uncontaminated at 8 week. 


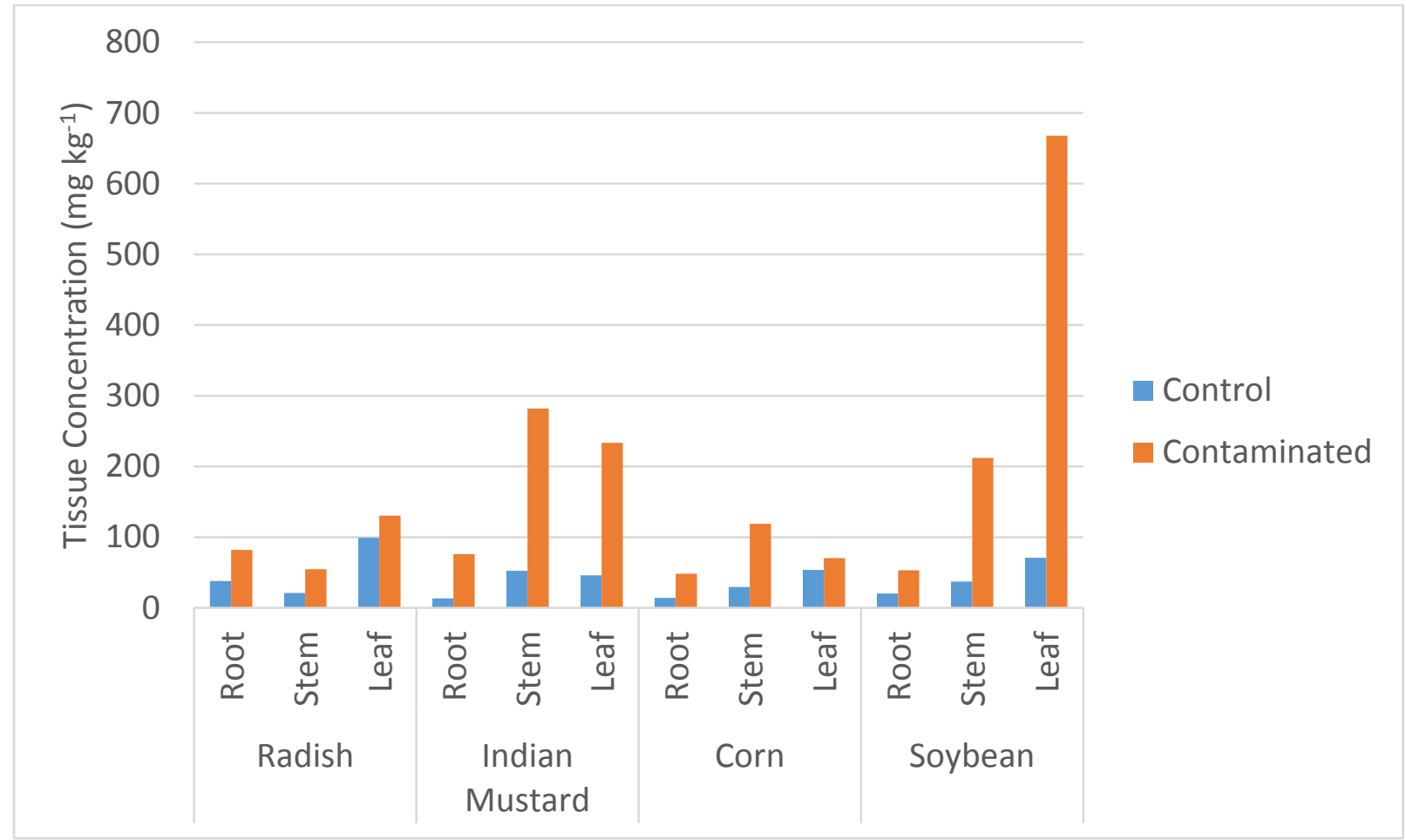

Figure 2-16 Mean Mn concentration in contaminated soil compared with uncontaminated at 8 week. 


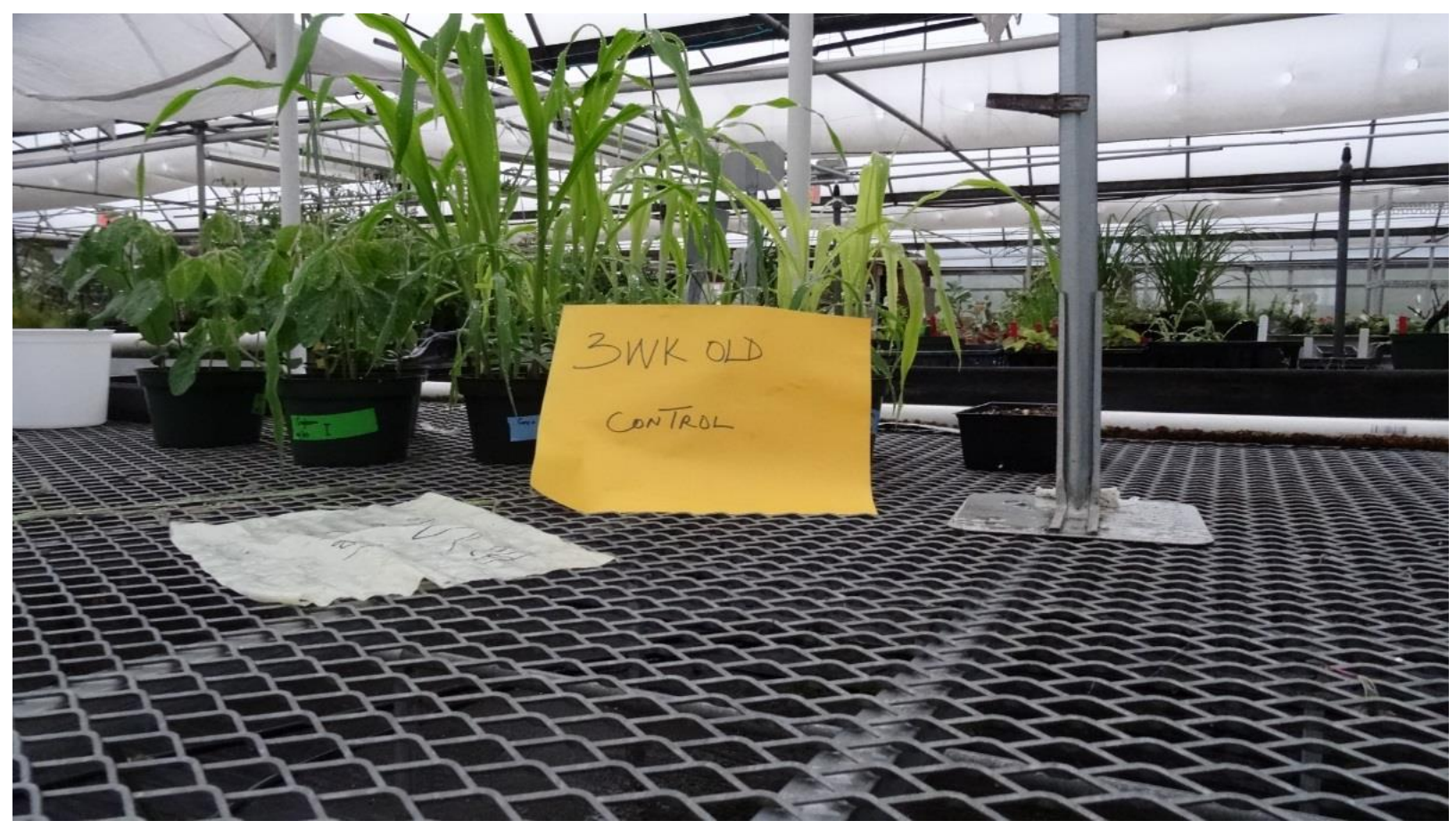

Figure 2-17 Control plants grown on greenhouse media- healthy with no visible symptoms. 